\title{
Transport Metabolons and Acid/Base Balance in Tumor Cells
}

\author{
Holger M. Becker ${ }^{1, *(D)}$ and Joachim W. Deitmer ${ }^{2}$ \\ 1 Institute of Physiological Chemistry, University of Veterinary Medicine Hannover, D-30559 Hannover, \\ Germany \\ 2 Department of Biology, University of Kaiserslautern, D-67653 Kaiserslautern, Germany; \\ deitmer@biologie.uni-kl.de \\ * Correspondence: holger-becker@online.de
}

Received: 10 February 2020; Accepted: 4 April 2020; Published: 7 April 2020

check for updates

\begin{abstract}
Solid tumors are metabolically highly active tissues, which produce large amounts of acid. The acid/base balance in tumor cells is regulated by the concerted interplay between a variety of membrane transporters and carbonic anhydrases (CAs), which cooperate to produce an alkaline intracellular, and an acidic extracellular, environment, in which cancer cells can outcompete their adjacent host cells. Many acid/base transporters form a structural and functional complex with CAs, coined "transport metabolon". Transport metabolons with bicarbonate transporters require the binding of CA to the transporter and CA enzymatic activity. In cancer cells, these bicarbonate transport metabolons have been attributed a role in $\mathrm{pH}$ regulation and cell migration. Another type of transport metabolon is formed between CAs and monocarboxylate transporters, which mediate proton-coupled lactate transport across the cell membrane. In this complex, CAs function as "proton antenna" for the transporter, which mediate the rapid exchange of protons between the transporter and the surroundings. These transport metabolons do not require CA catalytic activity, and support the rapid efflux of lactate and protons from hypoxic cancer cells to allow sustained glycolytic activity and cell proliferation. Due to their prominent role in tumor acid/base regulation and metabolism, transport metabolons might be promising drug targets for new approaches in cancer therapy.
\end{abstract}

Keywords: carbonic anhydrase; proton antenna; tumor metabolism; tumor cell migration

\section{Introduction}

The activity of many proteins is strongly influenced by their state of protonation. Therefore, intracellular and extracellular $\mathrm{pH}$ have to be tightly controlled to allow normal cell function. In healthy tissue, intracellular $\mathrm{pH}\left(\mathrm{pH}_{\mathrm{i}}\right)$ is set to around neutral, while extracellular $\mathrm{pH}\left(\mathrm{pH}_{\mathrm{e}}\right)$ is slightly alkaline [1,2]. In tumors, however, alterations in cell metabolism and the acid/base regulator machinery result in drastic changes in intracellular and extracellular $\mathrm{pH}$, with a slightly alkaline $\mathrm{pH}_{\mathrm{i}}$ and acidic $\mathrm{pH}_{\mathrm{e}}$, which can drop down to values as low as 6.5 [3-5]. This extreme $\mathrm{pH}$ gradient seems to be a ubiquitous feature of malignant tumors, which appears already at an early stage of carcinogenesis, independent from the tumor's origin and genetic background $[6,7]$. Alterations in intracellular and extracellular $\mathrm{pH}$, in turn, trigger a variety of physiological responses, which drive tumor progression. The slight increase in $\mathrm{pH}_{\mathrm{i}}$ supports cell proliferation and inhibits apoptosis [8-11]. Furthermore, a high $\mathrm{pH}_{\mathrm{i}}$ activates cofilin, which supports cell migration by reorganization of the actin cytoskeleton [12,13]. Finally, the intracellular alkalinization enhances glycolysis, which results in an increased production of acid and exacerbates extracellular acidification. Extracellular acidification can kill adjacent host cells and suppresses an immune response by inhibiting T-cell activation and impaired chemotaxis $[14,15]$. 
Furthermore, the low $\mathrm{pH}_{\mathrm{e}}$ supports degradation of the extracellular matrix (ECM) and thereby contributes to tumor cell migration and invasion $[13,16]$.

$\mathrm{pH}$ regulation in tumor cells is governed by the concerted interplay between various acid/base transporters and carbonic anhydrases. The major $\mathrm{pH}$ regulator in cancer cells is the $\mathrm{Na}^{+} / \mathrm{H}^{+}$exchanger 1 (NHE1). The expression of NHE1 is upregulated already in an early stage in tumorigenesis [6]. Oncogene-induced activation of NHE1 drives both intracellular alkalization and extracellular acidification, and was therefore suggested to play a key role in the malignant transformation of solid tumors [6,17]. Furthermore, NHE1, which accumulates in the leading edge of migrating cells, has been attributed a central role in cell migration and invasion [18-21]. However, other NHE isoforms, like NHE 6 and NHE9, have also been attributed important roles in tumor $\mathrm{pH}$ regulation, carcinogensis, and the development of chemoresistance [22-24]. NHE6 was shown to relocate from the endosomes to the plasma membrane, triggering endosome hyperacidification and chemoresistance in human MDA-MB-231 and HT-1080 cells [24].

Proton extrusion from cancer cells is further mediated by the monocarboxylate transporters MCT1 and MCT4, which are upregulated in a variety of tumor types [25-28]. MCTs transport lactate, but also other metabolites like pyruvate, ketone bodies, or branched-chain ketoacids, in cotransport with $\mathrm{H}^{+}$ across the plasma membrane [29-32]. Lactate-coupled proton extrusion from highly glycolytic cancer cells can exacerbate extracellular acidification and contribute to malignant transformation [33].

Besides the constant extrusion of protons, intracellular $\mathrm{pH}$ is regulated by the $\mathrm{Na}^{+} / \mathrm{HCO}_{3}{ }^{-}$ cotransporters NBCe1 and NBCn1. The electroneutral NBCn1 transports $\mathrm{Na}^{+}$and $\mathrm{HCO}_{3}{ }^{-}$in a 1:1 stoichiometry, while the electrogenic NBCe1 operates at a $1 \mathrm{Na}^{+} / 2 \mathrm{HCO}_{3}{ }^{-}$or $1 \mathrm{Na}^{+} / 3 \mathrm{HCO}_{3}{ }^{-}$ stoichiometry, depending on the phosphorylation state of the transporter [34-36]. Indeed, NBCs have been suggested to be the major acid extruders $\left(\mathrm{HCO}_{3}{ }^{-}\right.$importers $)$in some breast cancer cells $[37,38]$. During cell migration, $\mathrm{NBCs}$ contribute to local $\mathrm{pH}$ changes by importing $\mathrm{HCO}_{3}{ }^{-}$at the cell's leading edge $[13,39]$. In this compartment, $\mathrm{NBC}$ c cooperate with the $\mathrm{Cl}^{-} / \mathrm{HCO}_{3}{ }^{-}$exchanger $\mathrm{AE2}$, which extrudes $\mathrm{HCO}_{3}{ }^{-}$in exchange for osmotically active $\mathrm{Cl}^{-}$to support local cell swelling $[13,39]$. The function of the various bicarbonate transporters in tumor acid/base regulation has been extensively discussed in several review articles [38,40,41].

Tumor $\mathrm{pH}$ regulation is further supported by carbonic anhydrases (CAs), which catalyze the reversible hydration of $\mathrm{CO}_{2}$ to $\mathrm{HCO}_{3}{ }^{-}$and $\mathrm{H}^{+}$. Out of the 12 catalytically active $\mathrm{CA}$ isoforms expressed in humans, CAIX and CAXII have been attributed a distinct role in tumor $\mathrm{pH}$ regulation. In healthy tissue, the expression of CAIX is mainly restricted to the stomach and intestine. In cancer cells, however, the expression of CAIX is often upregulated and correlates with chemoresistance and poor clinical outcome [42-44]. The expression of CAIX is controlled by the hypoxia-inducible factor (HIF-1 $\alpha$ ), and therefore CAIX is primarily (but not exclusively) found in hypoxic tumor regions. CAIX comprises an exofacial catalytic domain, which is tethered to the plasma membrane with a single transmembrane domain, and an N-terminal proteoglycane-like (PG) domain, which is unique to CAIX amongst the carbonic anhydrases. The PG domain, which is rich in glutamate and aspartate residues, was suggested to function as a proton buffer for the catalytic domain and contributes to the formation of focal adhesion contacts $[45,46]$. In tumor tissue, CAIX functions as a "pH-stat", which stabilizes the extracellular $\mathrm{pH}$ to 6.8 [47]. Like CAIX, CAXII is often upregulated in tumor cells; however, the isoform is, as compared to CAIX, more abundant in healthy cells, too. In contrast to CAIX, expression of CAXII was correlated to both good and bad prognosis, depending on the tumor type $[48,49]$. However, CAXII seems to play a role in the development of multidrug resistance and was therefore suggested as a potential drug target to overcome chemoresistance [50,51].

Besides the extracellular CA isoforms IX and XII, different cytosolic CAs, like CAI and CAII, have been attributed a role in various tumor types. However, the function of cytosolic CAs for tumor development and progression has not been studied as extensively as for their exofacial counterparts. For a comprehensive review about the role of the different CA isoforms in tumor cells, see [52]. 


\section{Acid/Base Transport Metabolons}

Intracellular and extracellular carbonic anhydrases interact with acid/base transporters, including NHEs, NBCs, AEs, and MCTs, to form a protein complex coined "transport metabolon". A transport metabolon was defined as a "temporary, structural-functional, supramolecular complex of sequential metabolic enzymes and cellular structural elements, in which metabolites are passed from one active site to another, without complete equilibration with the bulk cellular fluids (channelling)" [53-55].

The best studied CA isoform that interacts with acid/base transporters is the intracellular CAII. CAII was shown to bind to an acidic motive ( ${ }^{886} \mathrm{DADD}$ ) in the C-terminal tail of the $\mathrm{Cl}^{-} / \mathrm{HCO}_{3}{ }^{-}$ exchanger AE1 (band3) [56-58] (which is also expressed in different types of cancer, including gastric, colonic, and esophageal cancer $[59,60])$. Inhibition of CAII catalytic activity or overexpression of the catalytically inactive mutant CAII-V143Y reduced the transport activity of AE1, expressed in human embryonic kidney 293 (HEK-293) cells [61]. Based on these results, it was suggested that CAII, which is directly bound to the transporter, could locally provide $\mathrm{HCO}_{3}{ }^{-}$to the exchanger. Thereby, CAII counteracts local depletion of $\mathrm{HCO}_{3}{ }^{-}$and stabilizes the substrate pool for the transporter (Figure 1A).
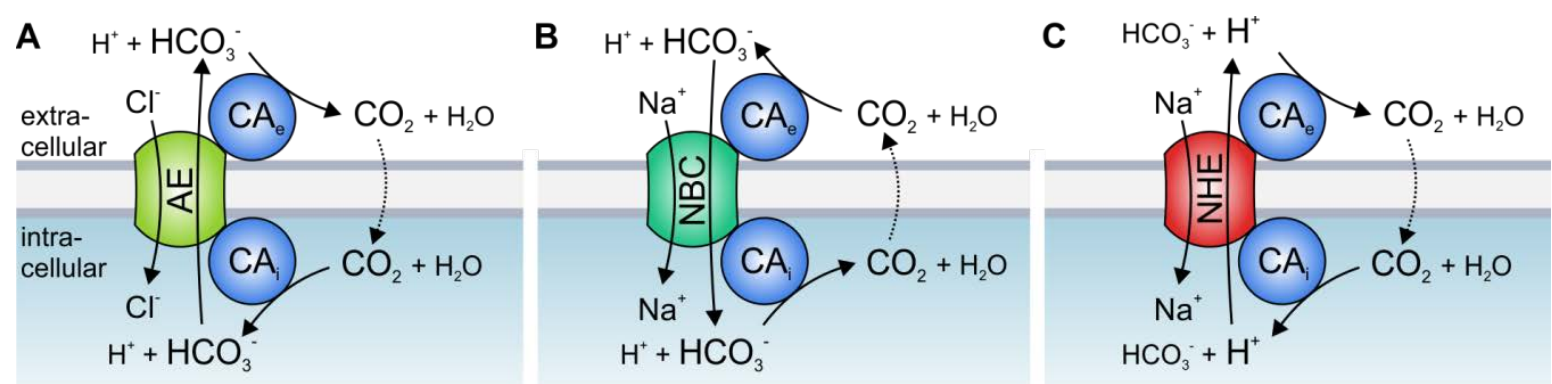

Figure 1. Hypothetical model of the interaction between acid/base transporters and carbonic anhydrases (CAs). Cytosolic CAs bind to the C-terminal tail of various isoforms of (A) $\mathrm{Cl}^{-} / \mathrm{HCO}_{3}{ }^{-}$exchangers (AEs), (B) $\mathrm{Na}^{+} / \mathrm{HCO}_{3}{ }^{-}$cotransporters (NBCs), and (C) $\mathrm{Na}^{+} / \mathrm{H}^{+}$exchangers (NHEs), while exofacial $\mathrm{CAs}$ bind to an extracellular domain of the transporters. By catalyzing the reversible hydration of $\mathrm{CO}_{2}$ to $\mathrm{HCO}_{3}{ }^{-}$and $\mathrm{H}^{+}$in the direct vicinity of the transporter, $\mathrm{CAs}$ provide $\mathrm{HCO}_{3}{ }^{-}$or $\mathrm{H}^{+}$at the cis side and remove the $\mathrm{HCO}_{3}{ }^{-}$or $\mathrm{H}^{+}$on the trans side of the transporter.

CAII was also found to bind to, and facilitate the transport activity of, the $\mathrm{Na}^{+} / \mathrm{HCO}_{3}{ }^{-}$ cotransporters NBCe1 and NBCn1 [62-66], as well as the $\mathrm{Na}^{+} / \mathrm{H}^{+}$exchangers NHE1 and NHE3 [67-69]. CAII-mediated facilitation of NBC and NHE transport activity requires direct binding of the enzyme to an acidic cluster in the transporters' C-terminal tail, as well as CAII catalytic activity. In the case of $\mathrm{NBC}$, CAII would either provide or remove $\mathrm{HCO}_{3}{ }^{-}$to/from the transporter, while in the case NHE, CAII would provide $\mathrm{H}^{+}$(Figure 1B,C).

The activity of $\mathrm{HCO}_{3}{ }^{-}$transporters is also facilitated by direct and functional interaction with extracellular CA isoforms. CAIV was shown to bind to the fourth extracellular loop of both AE1 and NBCe1 [70,71]. The binding of CAIV as well as CAIV enzymatic activity is mandatory for the CAIV-mediated increase in $\mathrm{HCO}_{3}{ }^{-}$transport. Thereby, CAIV would form the extracellular part of the transport metabolon, which provides or removes $\mathrm{HCO}_{3}{ }^{-}$to/from the transporter to stabilize the $\mathrm{HCO}_{3}{ }^{-}$gradient for maximum transport function (Figure 1A,B). In the case of NHE, CAIV would remove protons from the transporter to stabilize the $\mathrm{H}^{+}$gradient (Figure 1C). The transport activity of $\mathrm{Cl}^{-} / \mathrm{HCO}_{3}{ }^{-}$exchangers is not only facilitated by CAIV but also by CAIX, the catalytic domain of which binds to AE1, AE2, and AE3 to support $\mathrm{Cl}^{-} / \mathrm{HCO}_{3}{ }^{-}$transport activity [72,73]. An overview of the various types of acid/base transport metabolons described so far is given in Table 1. 
Table 1. Overview of the known interactions between acid/base transporters and carbonic anhydrases. Combinations of CAs and transporters for which an interaction was demonstrated are indicated with $\square$. CAs and transporters that have been shown not to interact are indicated with . Transport metabolons that have been shown in cancer cells are marked in red. For every CA, the left column indicates functional interaction. The right column indicates physical interaction. * CAIV and CAIX interact with MCT1, MCT2, and MCT4 via their chaperons CD (cluster of difference) 147 and GP70.

\begin{tabular}{|c|c|c|c|c|c|c|c|c|c|c|c|}
\hline \multirow{3}{*}{$\begin{array}{l}\text { Transporter } \\
\text { AE1 (SLC4A1) }\end{array}$} & \multicolumn{10}{|c|}{ Interacts with CA Isoform } & \multirow{3}{*}{$\begin{array}{l}\text { Reference } \\
{[39,56-58,61,70,72,74-76]}\end{array}$} \\
\hline & CA I & \multicolumn{2}{|c|}{ CA II } & \multirow[t]{2}{*}{ CA III } & \multicolumn{2}{|c|}{ CA IV } & \multicolumn{2}{|c|}{ CA IX } & \multicolumn{2}{|c|}{ CA XIV } & \\
\hline & 図 & 甲 & 田 & & 甲 & च & 口 & 口 & & & \\
\hline AE2 (SLC4A2) & & 口 & ஏ & & 甲 & & 田 & 曰 & & & {$[39,57,61,70]$} \\
\hline AE3 (SLC4A3) & & $\nabla$ & & & $\square$ & & $\square$ & 口 & 甲 & 口 & {$[61,70,72,77]$} \\
\hline DRA (SLC26A3) & & 甲 & $\otimes$ & & & & & & & & [70] \\
\hline SLC26A6 & & $\vec{\nabla}$ & $\square$ & & & & & & & & {$[78]$} \\
\hline SLC26A7 & & च & & & & & & & & & {$[72]$} \\
\hline NBCe1 (SLC4A4) & 甲 & 口 & 田 & 口 & $\square$ & 口 & 口 & 口 & & & {$[39,62-66,71,73,79,80]$} \\
\hline NBCn1 (SLC4A7) & & 口 & च & & & & & & & & [64] \\
\hline NHE1 (SLC9A1) & & $\vec{\nabla}$ & $\square$ & & 甲 & & 甲 & ஏ & & & {$[67,79,81-83]$} \\
\hline NHE3 (SLC9A3) & & $\square$ & 口 & & & & & & & & [68] \\
\hline SNAT1 (SLC38A3) & 口 & $\bar{\nabla}$ & & 口 & $\square$ & & & & & & {$[84,85]$} \\
\hline MCT1 (SLC16A1) & $\mathbf{x}$ & च & 甲 & 园 & 甲 & ஏ* & 田 & 曰 & & & [86-96] \\
\hline MCT2 (SLC16A7) & & 园 & 园 & & $\bar{\nabla}$ & 可 & & & & & {$[94,95,97,98]$} \\
\hline MCT4 (SLC16A3) & & 口 & 甲 & 図 & 甲 & 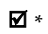 & 田 & 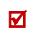 & & & {$[88,90,92,94,95,98-101]$} \\
\hline
\end{tabular}

Even though there is accumulating evidence for the physical and functional interaction between acid/base transporters and CAs, both in vitro and in intact cells, several studies have questioned the existence of bicarbonate transport metabolons, both in respect to the physical as well as functional interaction between CAs and transport proteins [102-105]. For a comprehensive review on bicarbonate transport metabolons, including the criticism on this concept, we recommend the reviews [55,106-108].

A different type of transport metabolon is formed between intracellular and extracellular CAs and MCTs. In marked contrast to the transport metabolons formed with $\mathrm{HCO}_{3}{ }^{-}$transporters, the facilitation of MCT activity is independent of CA catalytic activity [86-88,99]. In fact, the CAs seem to function as a "proton antenna", which moves $\mathrm{H}^{+}$between the MCT transporter pore and surrounding protonatable residues [88]. Proton-collecting antennae have been described for different $\mathrm{H}^{+}$-transporters, including cytochrome c oxidase and bacteriorhodopsin $[109,110]$. A proton-collecting antenna is comprised of several acidic glutamate and aspartate residues, which function as " $\mathrm{H}^{+}$ collectors", and histidine residues, which function as " $\mathrm{H}^{+}$retainers". The antenna accelerates the protonation rate of functional groups and creates a "proton reservoir" on the protein surface [111]. CAII facilitates the transport activity of MCT1 and MCT4, when heterologously expressed in Xenopus oocytes [86,99]. Pharmacological inhibition of CAII catalytic activity as well as co-expression of the catalytically inactive mutant CAII-V143Y did not suppress CAII-mediated augmentation of MCT transport activity, indicating that the CAII-MCT1/4 metabolon functions independently of the CAII catalytic activity [86-88,99]. However, CAII-mediated facilitation of MCT1/4 activity requires direct binding of the enzyme to a cluster of three glutamic acid residues in the transporters' C-terminal tail $[89,98]$. Interestingly, the transport activity of MCT2, which does not feature a CAII binding site, is not facilitated by co-expression with CAII [97]. However, integration of a CAII binding site into the MCT2 C-terminal tail allows CAII to facilitate MCT2 transport activity when heterologously expressed in Xenopus oocytes [98]. The binding of CAII to the MCT C-terminal tail is mediated by CAII-His64 [92]. Interestingly, His64 forms the central residue of the CAII intramolecular $\mathrm{H}^{+}$shuttle, which is crucial for CAII to achieve high catalytic rates [112]. However, CAII-His64 does not participate in $\mathrm{H}^{+}$shuttling between the transporter and enzyme [92]. This $\mathrm{H}^{+}$shuttle seems to be mediated by the amino acids Glu69 and Asp72, which have been suggested to form a part of the CAII proton-collecting antenna $[92,113]$. Based on these results, it was suggested that CAII, which is directly bound to MCT1/4, facilitates parts of its proton-collecting apparatus to quickly move $\mathrm{H}^{+}$between the transporter and the surrounding protonatable residues near the inner face of the cell membrane. Thereby, CAII functions as a proton antenna for the $\mathrm{MCT}$, and counteracts the formation of $\mathrm{H}^{+}$nanodomains (local accumulation 
or depletion of $\mathrm{H}^{+}$) around the transporter pore, which would impair proton-coupled lactate flux (Figure 2) $[88,92,93,100]$.

A

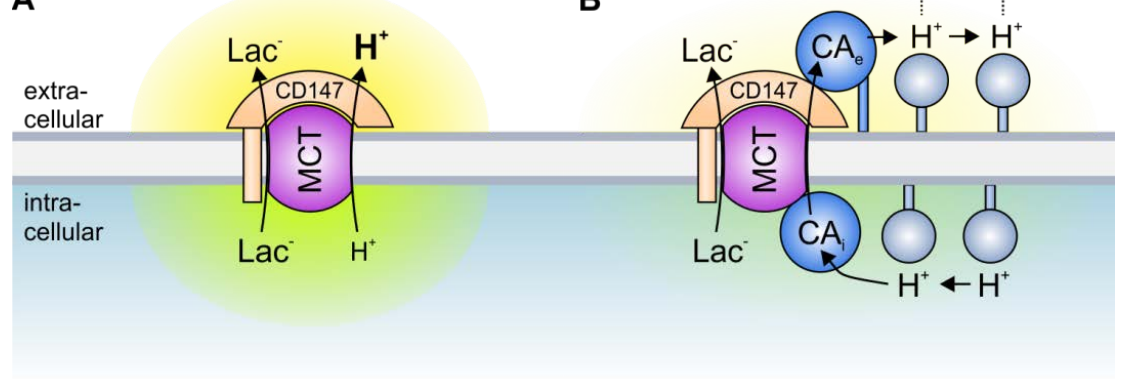

Figure 2. Transport metabolons with monocarboxylate transporters. (A) Due to the slow effective diffusion of protons (most protons are bound to bulky buffer molecules) MCT transport activity leads to the formation of proton nanodomains around the transporter pore. In the case of lactate and $\mathrm{H}^{+}$efflux, $\mathrm{H}^{+}$would locally deplete near the intracellular side of the membrane (green cloud) and locally accumulate near the extracellular side (yellow cloud). During lactate and $\mathrm{H}^{+}$influx, $\mathrm{H}^{+}$ would deplete near the extracellular side and accumulate near the intracellular side of the membrane. These proton nanodomains would in turn decrease MCT transport activity. (B) During lactate and $\mathrm{H}^{+}$efflux, intracellular CA $\left(\mathrm{CA}_{\mathrm{i}}\right)$, which is bound to the transporter's C-terminal tail, provides $\mathrm{H}^{+}$ from surrounding protonatable residues to the transporter (thereby functioning as "proton-collecting antenna" for the transporter), while extracellular CA ( $\left.\mathrm{CA}_{\mathrm{e}}\right)$, which binds to the Ig1 domain of the MCT chaperon $\mathrm{CD} 147$, removes $\mathrm{H}^{+}$from the transporter and shuttles them to surrounding protonatable residues ("proton-distributing antenna"). During lactate and $\mathrm{H}^{+}$influx, $\mathrm{CA}_{\mathrm{e}}$ would provide $\mathrm{H}^{+}$to the transporter, while $\mathrm{CA}_{\mathrm{i}}$ would remove the $\mathrm{H}^{+}$from the transporter pore. By this "push and pull" mechanism, intracellular and extracellular CAs counteract the formation of proton nanodomains to allow rapid transport of lactate and $\mathrm{H}^{+}$across the cell membrane.

MCT transport activity is not only facilitated by intracellular CAII but also by the extracellular isoforms CAIV and CAIX [90,91,94-97]. Up to now, the MCT-CAIV transport metabolon has only been investigated in Xenopus oocytes [90,94,97], while CAIX was shown to interact with MCTs both in the Xenopus oocyte expression system and in human breast cancer cell lines $[91,95,96]$. As already observed for CAII, the facilitation of MCT transport activity by extracellular CAs is independent of the enzymes' catalytic activity [91,97] but requires close association of the CA to the transporter [94,96]. Interestingly, CAIV and CAIX do not directly bind to the transporter but to the first globular (Ig1) domain of the MCT chaperons CD147 (MCT1 and MCT4) and GP70 (MCT2) [94,97]. In both carbonic anhydrases, this binding is mediated by a histidine residue that is analogue to His64 in CAII (CAIV-His88 and CAIX-His200) $[91,94,96]$. Proton shuttling between MCTs and CAIX seems to be mediated by the CAIX PG domain, which features 18 glutamate and 8 aspartate residues. These acidic residues could function as proton antenna for the protein complex [96,114]. The proton antenna in CAIV is yet unidentified. Both CAIV and CAIX have been suggested to function as an extracellular $\mathrm{H}^{+}$antenna for MCTs, which shuttles $\mathrm{H}^{+}$between the transporter and surrounding protonatable residues, thereby counteracting the formation of extracellular $\mathrm{H}^{+}$nanodomains (Figure 2) $[91,94,96]$. Since dissipation of the proton nanodomain on only one side of the membrane could exacerbate the accumulation or depletion of protons on the other side, due to increased MCT transport activity, and intracellular and extracellular CAs have to work in concert for efficient proton handling on both sides of the membrane to allow maximum MCT transport activity (Figure 2) [90,93].

Besides cancer cells, transport metabolons have also been suggested to operate in various cells and tissues, including erythrocytes (AE1-CAII) [56], kidney (NBCe1-CAII; NHE3-CAII) [63,68], gastric mucosal epithelium (AE2-CAIX) [72], heart muscle (NHE1-CAII; AE3-CAII) [69,115], and brain (MCT1-CAII; MCT-CAIV/CAXIV; AE3-CAIV/CAXIV) [89,116,117]. 


\section{The Role of Transport Metabolons in Tumor Metabolism}

Solid tumors, which often have to cope with acute local hypoxia, are highly glycolytic tissues, which produce large amounts of lactate and protons $[118,119]$. Proton-coupled lactate extrusion from cancer cells is primarily mediated by the monocarboxylate transporters MCT1 and MCT4 [25-28]. The constant efflux of acid into the pericellular space supports the formation of a hostile tumor microenvironment, in which tumor cells can outcompete their normal host cells [94]. Lactate production is increased under hypoxia, resulting in the need for enhanced lactate export capacity in cancer cells [91,120,121]. This increase in lactate transport could either be mediated by increased MCT expression levels or by the facilitation of MCT transport function through the formation of a transport metabolon [91,122,123]. Transport metabolons, formed between MCT1/MCT4 and CAIX, were found in tissue samples of human breast cancer patients but are absent in healthy breast tissue [96]. Interestingly, the number of MCT1/4-CAIX interactions, as shown by an in situ proximity ligation assay (PLA), increased with increasing tumor grade [96]. The increase in glycolysis, as found in higher grade tumors [124], appears to require a higher lactate efflux capacity in cells, which is achieved by an increasing number of transport metabolons [96]. Thereby, CAIX-facilitated $\mathrm{H}^{+} /$lactate efflux would enable sustained energy production in glycolytic cancer cells to allow continued cell proliferation and tumor progression. Increased glycolysis is often initiated by hypoxia [119,125]. In line with this, MCT1/4-CAIX transport metabolons were found in hypoxic MCF-7 and MDA-MB-231 breast cancer cells but not in normoxic cells [96]. Both breast cancer cell lines show an increase in glycolysis under hypoxia, which is accompanied by an increase in lactate transport capacity [91,96]. This hypoxia-induced increase in lactate transport is not mediated by increased expression of monocarboxylate transporters but by the non-catalytic function of CAIX, the expression of which is highly increased in MCF-7 and MDA-MB-231 cells under hypoxia [91]. Indeed, both knockdown of CAIX with siRNA, as well as application of an antibody against the CAIX PG domain blocked the hypoxia-induced increase in lactate flux, while inhibition of CA enzymatic activity with 6-ethoxy-2-benzothiazolesulfonamide (EZA) or an antibody directed against the CAIX catalytic domain did not affect lactate transport [91,95]. These data let to the conclusion that CAIX, the expression of which is increased under hypoxia, forms a non-catalytic transport metabolon with MCT1 and MCT4 to facilitate $\mathrm{H}^{+}$-coupled lactate efflux from glycolytic breast cancer cells. The rapid extrusion of lactate and $\mathrm{H}^{+}$allows sustained glycolytic activity and cell proliferation (Figure 3). Indeed, knockout of CAIX as well as the application of an antibody against the CAIX PG domain, but not inhibition of CA enzymatic activity, resulted in a significant reduction in the proliferation of hypoxic MCF-7 and MDA-MB-231 cells [91,95]. These data were confirmed in the triple-negative breast cancer cell line UFH-001 [101]. Knockdown of CAIX with a CRISPR/Cas9 approach decreased the glycolytic proton efflux rate (GlycoPER), as measured by Seahorse analysis, in pseudo-hypoxic UFH-001 cells treated with the HIF1 $\alpha$-stabilizing agent desferrioxamine (DFO). Yet, isoform-specific inhibition of CAIX catalytic activity with three ureido-substituted benzene sulfonamides (USBs) did not affect proton efflux, indicating that CAIX catalytic activity is not required to facilitate $\mathrm{H}^{+}$-coupled lactate flux in cancer cells.

Experiments on Xenopus oocytes and mathematical modeling have shown that efficient lactate shuttling via MCTs requires a carbonic anhydrase on both sides of the plasma membrane $[90,93]$. Even though the intracellular isoform CAII is not cancer specific, it is upregulated in different tumor cells, including breast, lung, colorectal, gastrointestinal, and prostate cancer [126-129]. PLA assays revealed that CAII is closely colocalized with MCT1 in MCF-7 cells [92]. In these cells, knockdown of CAII resulted in a significant decrease in lactate transport capacity [92]. Even though the expression of CAII is not increased under hypoxia, CAII knockdown had a stronger effect on lactate transport in hypoxic than in normoxic cells. Indeed, the hypoxia-induced increase in lactate transport, which is mediated by CAIX [91], was completely abolished in the absence of CAII. These results indicate that extracellular CAIX requires an intracellular counterpart to facilitate lactate transport from cancer cells. This is in line with previous findings that enhanced proton shuttling by a carbonic anhydrase on only one side of the plasma membrane creates a proton nanodomain on the opposing side, which in turn decelerates proton-coupled lactate flux [90,93]. During the efflux of lactate, CAII would collect protons from the intracellular face of the plasma membrane and shuttle them to the transporter pore. 
On the exofacial side, CAIX would remove the protons from the transporter and shuttle them to surrounding protonatable sites at the membrane. By this "push-and-pull" principle, intracellular CAII and extracellular CAIX would cooperate to ensure efficient efflux of lactate and protons from hypoxic cells to allow sustained glycolytic energy production (Figure 3). The removal of CA on either side of the membrane would lead to the formation of a proton domain around the MCT on this side and would therefore decrease MCT transport activity, which would lead to cytosolic accumulation of lactate and protons and ultimately to decreased glycolysis and cell proliferation. Indeed, this interpretation is supported by the finding that knockdown of either CAII or CAIX decreased cell proliferation in hypoxic MCF-7 breast cancer cells. For a comprehensive review about MCT transport metabolons in cancer cells, see also [130].

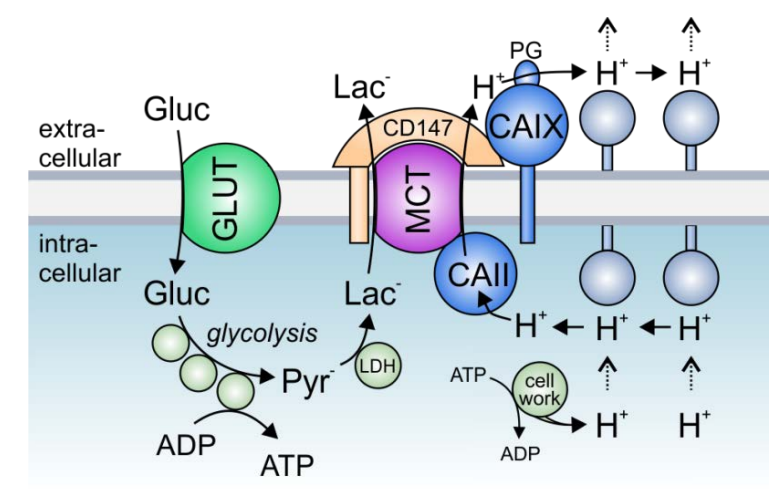

Figure 3. The role of lactate transport metabolons in cancer metabolism: Hypoxic tumors meet their energetic demand by glycolysis. Glucose, which is imported into the cell via glucose transporters (GLUTs), is metabolized to pyruvate, which in turn is converted to lactate by the enzyme lactate dehydrogenase (LDH). Lactate is exported in cotransport with protons (which are produced during metabolic activity) via monocarboxylate transporters (MCTs). In hypoxic cancer cells, MCT transport activity is facilitated by the interaction with intracellular CAII and extracellular CAIX, which directly bind to the transporters' C-terminal tail and the MCT chaperon CD147, respectively. In this protein complex, CAII and CAIX function as a "proton antennae", which facilitates the rapid exchange of $\mathrm{H}^{+}$ between the transporter pore and surrounding protonatable residues near the cell membrane. Thereby, CAII and CAIX drive the export of $\mathrm{H}^{+}$and lactate from the cell to allow a high glycolytic rate and support cell proliferation.

\section{The Role of Transport Metabolons in Tumor pH Regulation and Cell Migration}

$\mathrm{pH}$ regulation in cancer cells is governed by the concerted interplay between various acid/base transporters, which mediate the ion-coupled transport of $\mathrm{H}^{+}$or $\mathrm{HCO}_{3}{ }^{-}$across the cell membrane. Besides regulating cellular $\mathrm{pH}$, many of these transporters have been attributed a central function in the initiation and regulation of cell migration and invasion [13]. Tumor cell migration is a multistep process, which requires the degradation of the extracellular matrix (ECM) by extrusion of acid and proteolytic enzymes, reorganization of the actin cytoskeleton, and coordinated formation and release of focal adhesion contacts between the cell and ECM [13]. All these processes are $\mathrm{pH}$ dependent and are therefore controlled by the regulatory machinery of the cell's acid/base-status. The major $\mathrm{pH}$ regulator in cell migration is the $\mathrm{Na}^{+} / \mathrm{H}^{+}$exchanger NHE1, which is redirected to the cell's leading edge during the onset of migration and accumulates in the lamellipodia of migrating cells $[13,18,131]$. NHE1-driven proton extrusion at the protruding front leads to the formation of a $\mathrm{pH}$ gradient along the cell, with a low $\mathrm{pH}_{\mathrm{e}}$ and a high $\mathrm{pH}_{\mathrm{i}}$. Extracellular acidification facilitates degradation of the ECM and supports the formation of focal adhesion contacts via the activation of integrins [132-134]. Intracellular alkalinization promotes the activity of cofilin [12], which produces free barbed ends in the actin cytoskeleton, thereby inducing actin branching and the growth of actin filaments into the protruding front, which pushes forward the leading edge. NHE1 also organizes the shape of the cytoskeleton during migration by directly acting as a plasma membrane 
anchor for actin filaments [135]. Furthermore, NHE1-mediated $\mathrm{Na}^{+}$influx drives osmotic swelling by water influx via aquaporins (Figure 4) $[13,136,137]$. pH regulation in the lamellipodia is further supported by $\mathrm{Na}^{+} / \mathrm{HCO}_{3}{ }^{-}$cotransporters (either NBCe1 or NBCn1), which are found in the leading edge of migrating cells, where the $\mathrm{Na}^{+}$-coupled import of $\mathrm{HCO}_{3}{ }^{-}$via NBCs contributes to the formation of an acidic $\mathrm{pH}_{\mathrm{e}}$ and alkaline $\mathrm{pH}_{\mathrm{i}}[39,138]$. Another acid/base transporter, which is found in the lamellipodia of migrating tumor cells, is the $\mathrm{Cl}^{-} / \mathrm{HCO}_{3}{ }^{-}$exchanger AE2 [131]. Even though AE2-mediated transport of $\mathrm{HCO}_{3}{ }^{-}$ could contribute to intracellular $\mathrm{pH}$ regulation, the major role of $\mathrm{AE} 2$ in cell migration seems to be the facilitation of isosmotic cell swelling. Like NHE1 and NBC, AE2 accumulates at the leading edge of migrating cells [131], where it mediates the import of osmotically active $\mathrm{Cl}^{-}$for the exchange of $\mathrm{HCO}_{3}{ }^{-}$. In this respect, AE2 could functionally cooperate with NBCs. A fraction of the $\mathrm{HCO}_{3}{ }^{-}$, which is imported by NBCs in cotransport with $\mathrm{Na}^{+}$, is again extruded by AE2 for the exchange of $\mathrm{Cl}^{-}$. This " $\mathrm{HCO}_{3}{ }^{-}$ short circuit" results in the net uptake of osmotically active $\mathrm{Na}^{+}$and $\mathrm{Cl}^{-}$and promotes water uptake via aquaporins and local swelling of the lamellipodia (Figure 4) $[13,39,131]$. In the thin lemellipodia, which do not contain mitochondria, energy is mainly produced by glycolysis, which generates $\mathrm{H}^{+}$and lactate. Both lactate and $\mathrm{H}^{+}$are extruded by MCT4, which has been shown to accumulate at the leading edge of migrating cells and therefore contributes to extracellular acidification [139]. For a detailed review on the role of $\mathrm{pH}$ in cell migration, see $[7,13,140,141]$.

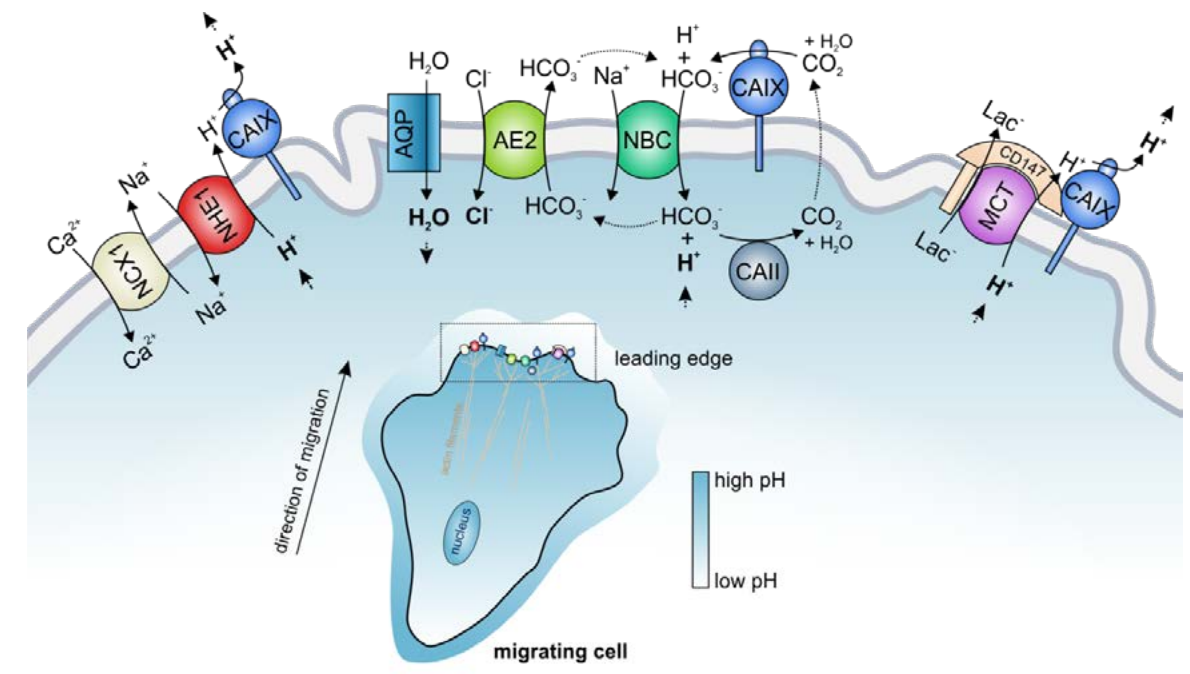

Figure 4. The function of transport metabolons in cancer cell migration. Tumor cell migration is a multistep process, which requires reversal of the $\mathrm{pH}$ gradient at the leading edge of the migrating cell. In most cancer cells, $\mathrm{H}^{+}$extrusion is primarily mediated by the $\mathrm{Na}^{+} / \mathrm{H}^{+}$exchanger NHE1 in exchange for $\mathrm{Na}^{+}$. NHE1 transport activity was suggested to be facilitated by CAIX, which removes $\mathrm{H}^{+}$from the transporter pore. Protons are also removed by the monocarboxylate transporters MCT1 and MCT4 in cotransport with lactate. NHE1 transport activity could be further supported by the $\mathrm{Na}^{+} / \mathrm{Ca}^{2+}$ exchanger NCX1, which removes cytosolic $\mathrm{Na}^{+}$by the exchange of $\mathrm{Na}^{+}$for $\mathrm{Ca}^{2+}$. CAIX facilitates MCT1/4 transport activity by functioning as a proton antenna for the transporter, which removes $\mathrm{H}^{+}$from the extracellular face of the transporter. The $\mathrm{Na}^{+} / \mathrm{HCO}_{3}{ }^{-}$cotransporters $\mathrm{NBCe} 1$ and $\mathrm{NBCn} 1$ contribute to acid extrusion by $\mathrm{Na}^{+}$-coupled import of $\mathrm{HCO}_{3}{ }^{-}$. In the cytosol, $\mathrm{HCO}_{3}{ }^{-}$ binds $\mathrm{H}^{+}$, forming $\mathrm{CO}_{2}$, which can diffuse out of the cell. At the cell surface, CAIX hydrates $\mathrm{CO}_{2}$ again to $\mathrm{HCO}_{3}{ }^{-}$and $\mathrm{H}^{+}$, and $\mathrm{HCO}_{3}{ }^{-}$can be reimported into the cell. A fraction of the intracellular $\mathrm{HCO}_{3}{ }^{-}$can again be exported by AE2 in exchange for $\mathrm{Cl}^{-}$. This " $\mathrm{HCO}_{3}{ }^{-}$short circuit" results in cytosolic accumulation of osmotically active $\mathrm{Na}^{+}$and $\mathrm{Cl}^{-}$, which facilitates water influx by aquaporins (AQPs) and supports local cell swelling. This complex interplay between acid/base transporters and carbonic anhydrases creates a $\mathrm{pH}$ gradient along the migrating cell with a low $\mathrm{pH}_{\mathrm{e}}$ and a high $\mathrm{pH}_{\mathrm{i}}$ at the protruding front, as shown in the inset picture. 
Interestingly, the transporters mentioned above have been found to interact with CAIX in cancer cells. CAIX itself, which is redistributed to the lamellipodia of migrating cells $[39,46]$, plays a central role in tumor cell migration and invasion [80,142]. CAIX catalytic activity is required for the generation of acidic $\mathrm{pH}_{\mathrm{e}}$ nanodomains, which are mandatory for proteolytic cleavage of the ECM [80]. Furthermore, CAIX directly interacts with different actin-regulating proteins in the cytosol [80] and promotes focal cell adhesion through its extracellular PG domain [46].

First evidence for the formation of transport metabolons in migrating tumor cells was presented in 2012 [39]. The authors showed by PLA that CAIX is closely colocalized with NBCe1 in the lamellipodia of hypoxic A549 adenocarcinomic human alveolar basal epithelial cells [39]. The same group also confirmed the colocalization of CAIX with NBCe1 in the invadopodia of hypoxic HT1080 fibrosarcoma cells [80]. Knockdown of the CAIX protein, as well as pharmacological inhibition of CAIX enzymatic activity or overexpression of a catalytically inactive CAIX mutant, resulted in a decrease in cell migration as well as reduced formation of invadopodia and proteolytic cleavage of the ECM. The authors further showed that application of monoclonal antibodies against the CAIX catalytic domain or the PG domain inhibits the metastatic properties of TE-1 human squamous cell carcinoma cells in a quail chorioallantoic membrane invasion assay and of HT-2018 cells in a mouse lung colonization assay [80]. Based on these results, the authors concluded that CAIX forms a transport metabolon with NBCe1 in the leading edge of migrating and invading tumor cells. This transport metabolon facilitates local bicarbonate uptake into the cells and thereby contributes to the formation of local $\mathrm{pH}_{\mathrm{i}}$ and $\mathrm{pH}_{\mathrm{e}}$ gradients, which drive remodeling of the actin cytoskeleton and proteolytic cleavage of the ECM $[35,80]$ (Figure 4). CAIX not only colocalizes with $\mathrm{NBCe} 1$ but also with the $\mathrm{Cl}^{-} / \mathrm{HCO}_{3}{ }^{-}$exchanger AE2 as shown by PLA in the lamellipodia of hypoxic SiHa cervical cancer cells [39]. The AE2-CAIX transport metabolon could either contribute to apparent $\mathrm{pH}_{\mathrm{i}}$ buffering or support cell swelling by the import of osmotically active $\mathrm{Cl}^{-}$(Figure 4). However, it should be noted that both studies did not directly measure the transport activity of NBCe1 and AE2 in the presence and absence of CAIX. Therefore, it could not be excluded that CAIX is not functionally linked to NBCe1 and AE2, even though it is in close proximity of the transporters.

CAIX was not only found to interact with bicarbonate transporters but also with the $\mathrm{Na}^{+} / \mathrm{H}^{+}$ exchanger NHE1 [81]. Co-immunoprecipitation of NHE1 and CAIX from hypoxic SiHa cells revealed direct binding between the two proteins. Interestingly, NHE1 not only co-precipitated with CAIX but also with the $\mathrm{Na}^{+} / \mathrm{Ca}^{2+}$ exchanger NCX1, which is closely colocalized to CAIX and NHE1 in hypoxic SiHa cells and RCC4 renal cell carcinoma cells, respectively. These data indicate that the three proteins form a transport metabolon to efficiently extrude protons from the cell. Thereby, CAIX would support the removal of $\mathrm{H}^{+}$from the extracellular face of the NHE1 (possibly by functioning as a proton antenna for the transporter), while NCX1 would remove cytosolic $\mathrm{Na}^{+}$by the exchange of $\mathrm{Na}^{+}$for $\mathrm{Ca}^{2+}$ [81]. The proton extrusion facilitates extracellular acidosis and thereby contributes to the formation of a hostile tumor microenvironment. Indeed, gene silencing of NCX1 and inhibition of NCX1 activity with KB-R7943 (which also resulted in a loss of NCX1-CAIX interaction) resulted in intracellular acidification in SiHa cells and increased the number of necrotic cells in SiHa spheroids. These results indicate that the NCX1-CAIX-NHE1 transport metabolon plays a crucial role in tumor pH regulation and cell survival. Furthermore, pharmacological inhibition of NCX1 transport activity with KB-R7943 reduced the migration of SiHa and RCC4 cells, which hints to an additional function of the protein complex in cell migration [81].

Acid extrusion from the highly glycolytic lamellipodia and invadopodia is also supported by MCTs, the activity of which is increased by the non-catalytic function of CAIX, as already described in the previous chapter (Figure 4). The application of an antibody against the CAIX PG domain, but not against the CAIX catalytic domain, inhibited MCT transport activity and cell migration in hypoxic MDA-MB-231 and MCF-7 breast cancer cells, indicating that the MCT-CAIX transport metabolon might also play a role in cell migration [95]. However, since the CAIX PG domain was also attributed a direct function in cell migration, these findings need further investigation. 
Taken together, it can be concluded that the transport metabolons, formed between CAIX and the membrane transporters NHE1, NBCe1, AE2, MCT4, and NCX1, play a crucial role in shaping intracellular and extracellular $\mathrm{pH}$ gradients at the protruding front of migrating tumor cells, thereby promoting tumor cell migration, invasion, and ultimately metastasis. Therefore, these transport metabolons are promising targets for novel drug therapies against cancer. However, further studies have to be performed to clarify the role of acid/base transport metabolons in tumor progression.

\section{Transport Metabolons as Drug Targets in Tumor Therapy}

Carbonic anhydrase inhibitors are used as pharmaceuticals in the treatment of different diseases, including glaucoma [143,144], epilepsy [145,146], and high-altitude illness [147,148]. Furthermore, several CA inhibitors are currently in clinical trial for the treatment of various types of solid tumors [149]. Transport metabolons, however, have not been subjected to preclinical investigation as drug targets for cancer therapy. Even though bicarbonate transport metabolons, per se, have not been investigated as drug targets, their dependence on carbonic anhydrase catalytic activity renders them susceptible to conventional CA inhibitors. Therefore, it should be kept in mind that part of the effect of CA inhibitors on tumor progression might be attributed to the inhibition of bicarbonate transport metabolons in cancer cells. Targeting acid/base transporters via their interaction with CAs could even be advantageous to direct inhibition of the transporters, since these transporters are not unique to cancer cells and therefore direct targeting of the transporter could cause severe side effects [150-152]. Transport metabolons, especially those formed with the cancer-related CA isoforms CAIX and CAXII, seem to be mostly restricted to cancer cells and should therefore be a more specific target as the transporters themselves. However, further studies are required to confirm this possibility.

In contrast to bicarbonate transport metabolons, transport metabolons formed between MCTs and CAs are independent from the CA catalytic activity [86-88]. Therefore, these transport metabolons should be resistant to classical CA inhibitors. Indeed, inhibition of CA catalytic activity with EZA had no effect on the lactate transport capacity or proliferation of hypoxic MCF-7 breast cancer cells [91]. In line with this, selective inhibition of CAIX with three different ureido-substituted benzene sulfonamides (USBs) did not alter the glycolytic rate in DFO-treated UFH-001 breast cancer cells, while CRISPR/Cas9-induced deletion of CAIX resulted in a significant reduction of glycolysis in the same cell type [101,153]. Since the transport metabolons formed between MCTs and CAIX are insensitive to the inhibition of CAIX catalytic activity, they have to be targeted either via the physical interaction between CAIX and the MCT chaperon CD147 or via the CAIX antennal function. Indeed, the application of an antibody against the CAIX PG domain, which was suggested to function as a proton antenna for the enzyme, reduced the lactate transport capacity and proliferation of hypoxic breast cancer cells [95]. The application of a monoclonal antibody directed against an epitope near the CAIX binding site in the Ig1 domain of CD147 resulted in the displacement of CAIX from the MCT1/4-CD147 complex, as shown by PLA in hypoxic MCF-7 cells [96]. This "metabolon disruption" decreased the lactate transport capacity in cancer cells, which led to a decrease in glycolytic activity and cell proliferation [96]. These findings provide a proof of concept that the transport metabolon formed between MCT1/4, CD147, and CAIX can be targeted to interfere with cancer cell metabolism and inhibit tumor progression.

\section{Conclusions}

Alterations in tumor metabolism and the machinery regulating the acid/base-status in cells result in a reversal in the $\mathrm{pH}$ gradient in solid tumors, with a slightly alkaline $\mathrm{pH}_{\mathrm{i}}$ and an acidic $\mathrm{pH}_{\mathrm{e}}$. This reversal in the $\mathrm{pH}$ gradient, which is considered a ubiquitous feature of solid tumors, triggers a variety of physiological responses, including increased glycolytic activity, enhanced cell proliferation, inhibition of apoptosis, immune escape, and cell migration. pH regulation in tumor cells is governed by the concerted interplay between various acid/base transporters, many of which form a physical and functional complex with CAs, coined "transport metabolon". Transport metabolons formed between the cancer-associated CAIX and $\mathrm{Cl}^{-} / \mathrm{HCO}_{3}{ }^{-}$exchangers (AEs), $\mathrm{Na}^{+} / \mathrm{HCO}_{3}{ }^{-}$cotransporters (NBCs), 
and $\mathrm{Na}^{+} / \mathrm{H}^{+}$exchangers (NHEs) require CAIX catalytic activity. These protein complexes, which are often found in the leading edge of migrating cells, have been attributed a role in tumor $\mathrm{pH}$ regulation and cell migration.

Transport metabolons formed between monocarboxylate transporters and CAIX/CAII are independent of the CA catalytic activity. In fact, CAIX and CAII seem to function as "proton antennae" for the transporter, which mediate the rapid exchange of $\mathrm{H}^{+}$between the transporter pore and surrounding protonatable residues. Since MCTs mediate the coupled efflux of protons and lactate from cancer cells, these transport metabolons have been suggested to play an important role in the energy metabolism of hypoxic tumor cells.

Due to their manifold functions in cancer cells, transport metabolons represent promising drug targets for tumor therapy. Since bicarbonate transport metabolons depend on CA catalytic activity, they could be targeted with classical CA inhibitors, some of which are already in clinical trials. For the MCT1/4-CAIX metabolon, which operates independently of CAIX catalytic activity, new therapeutic drugs have to be developed, which could function as "metabolon disruptors" that dislocate CAIX from the transporter-chaperon complex to inhibit proton-coupled lactate release from the cell.

Funding: The authors' own contributions to the field were funded by the Deutsche Forschungsgemeinschaft (BE 4310/6-1, to HMB and De 231/24 to JWD), the International Research Training Group (IRTG 1830/1) to HMB and JWD, the Research Initiative BioComp to HMB and JWD, the Stiftung Rheinland-Pfalz für Innovation (961-386261/957) to HMB and the Landesschwerpunkt Membrantransport to HMB and JWD.

Conflicts of Interest: The authors declare no conflict of interest.

\section{References}

1. Deitmer, J.W. Acid-base transport and $\mathrm{pH}$ regulation. In Handbook of Neurochemistry and Molecular Neurobiology—Brain Energetics. Integration of Molecular and Cellular Processes; Gibson, G.E., Dienel, G.A., Eds.; Springer: Berlin/Heidelberg, Germany, 2007; Volume 5, pp. 469-486.

2. Casey, J.R.; Grinstein, S.; Orlowski, J. Sensors and regulators of intracellular pH. Nat. Rev. Mol. Cell Biol. 2010, 11, 50-61. [CrossRef]

3. Griffiths, J.R.; Stevens, A.N.; Iles, R.A.; Gordon, R.E.; Shaw, D. 31P-NMR investigation of solid tumours in the living rat. Biosci. Rep. 1981, 1, 319-325. [CrossRef] [PubMed]

4. Gillies, R.J.; Liu, Z.; Bhujwalla, Z. 31P-MRS measurements of extracellular $\mathrm{pH}$ of tumors using 3-aminopropylphosphonate. Am. J. Physiol. Cell Physiol. 1994, 267, C195-C203. [CrossRef]

5. van Sluis, R.; Raghunand, N.; Bhujwalla, Z.M.; Cerdán, S.; Galons, J.; Ballesteros, P.; Gillies, R.J.; Alvarez, J. In vivo imaging of extracellular $\mathrm{pH}$ using $1 \mathrm{H}$ MRSI. Magn. Reson. Med. 2002, 41, 743-750. [CrossRef]

6. Reshkin, S.J.; Bellizzi, A.; Caldeira, S.; Albarani, V.; Malanchi, I.; Poignee, M.; Alunni-Fabbroni, M.; Casavola, V.; Tommasino, $\mathrm{M} . \mathrm{Na}^{+} / \mathrm{H}^{+}$exchanger-dependent intracellular alkalinization is an early event in malignant transformation and plays an essential role in the development of subsequent transformation-associated phenotypes. FASEB J. 2000, 14, 2185-2197. [CrossRef] [PubMed]

7. Cardone, R.A.; Casavola, V.; Reshkin, S.J. The role of disturbed $\mathrm{pH}$ dynamics and the $\mathrm{Na}^{+} / \mathrm{H}^{+}$exchanger in metastasis. Nat. Rev. Cancer 2005, 5, 786-795. [CrossRef] [PubMed]

8. Pouyssegur, J.; Sardet, C.; Franchi, A.; L'allemain, G.; Paris, S. A specific mutation abolishing $\mathrm{Na}^{+} / \mathrm{H}^{+}$antiport activity in hamster fibroblasts precludes growth at neutral and acidic $\mathrm{pH}\left(\mathrm{H}^{+}\right.$-suicide selection/cytoplasmic $\mathrm{pH} / \mathrm{Na}$ ' influx/growth control/somatic cell genetics). Cell Biol. 1984, 81, 4833-4837.

9. Pouyssegur, J.; Franchi, A.; L'Allemain, G.; Paris, S. Cytoplasmic pH, a key determinant of growth factor-induced DNA synthesis in quiescent fibroblasts. FEBS Lett. 1985, 190, 115-119. [CrossRef]

10. Matsuyama, S.; Reed, J.C. Mitochondria-dependent apoptosis and cellular $\mathrm{pH}$ regulation. Cell Death Differ. 2000, 7, 1155-1165. [CrossRef]

11. Grillo-Hill, B.K.; Choi, C.; Jimenez-Vidal, M.; Barber, D.L. Increased $\mathrm{H}^{+}$efflux is sufficient to induce dysplasia and necessary for viability with oncogene expression. Elife 2015, 2015, 1-31. [CrossRef]

12. Frantz, C.; Barreiro, G.; Dominguez, L.; Chen, X.; Eddy, R.; Condeelis, J.; Kelly, M.J.S.; Jacobson, M.P.; Barber, D.L. Cofilin is a $\mathrm{pH}$ sensor for actin free barbed end formation: Role of phosphoinositide binding. J. Cell Biol. 2008, 183, 865-879. [CrossRef] 
13. Stock, C.; Schwab, A. Protons make tumor cells move like clockwork. Pflugers Arch. 2009, 458, 981-992. [CrossRef] [PubMed]

14. Lardner, A. The effects of extracellular $\mathrm{pH}$ on immune function. J. Leukoc. Biol. 2001, 69, 522-530. [PubMed]

15. Pilon-Thomas, S.; Kodumudi, K.N.; El-Kenawi, A.E.; Russell, S.; Weber, A.M.; Luddy, K.; Damaghi, M.; Wojtkowiak, J.W.; Mulé, J.J.; Ibrahim-Hashim, A.; et al. Neutralization of Tumor Acidity Improves Antitumor Responses to Immunotherapy. Cancer Res. 2016, 76, 1381-1390. [CrossRef] [PubMed]

16. Monaco, S.; Gioia, M.; Rodriguez, J.; Fasciglione, G.F.; Di Pierro, D.; Lupidi, G.; Krippahl, L.; Marini, S.; Coletta, M. Modulation of the proteolytic activity of matrix metalloproteinase-2 (gelatinase A) on fibrinogen. Biochem. J. 2007, 402, 503-513. [CrossRef] [PubMed]

17. Andersen, A.P.; Samsøe-Petersen, J.; Oernbo, E.K.; Boedtkjer, E.; Moreira, J.M.A.; Kveiborg, M.; Pedersen, S.F. The net acid extruders NHE1, NBCn1 and MCT4 promote mammary tumor growth through distinct but overlapping mechanisms. Int. J. Cancer 2018, 1-14. [CrossRef]

18. Grinstein, S.; Woodside, M.; Waddell, T.K.; Downey, G.P.; Orlowski, J.; Pouyssegur, J.; Wong, D.C.; Foskett, J.K. Focal localization of the NHE-1 isoform of the $\mathrm{Na}^{+} / \mathrm{H}^{+}$antiport: Assessment of effects on intracellular $\mathrm{pH}$. EMBO J. 1993, 12, 5209-5218. [CrossRef]

19. Stock, C.; Mueller, M.; Kraehling, H.; Mally, S.; Noël, J.; Eder, C.; Schwab, A. pH nanoenvironment at the surface of single melanoma cells. Cell. Physiol. Biochem. 2007, 20, 679-686. [CrossRef]

20. Stüwe, L.; Müller, M.; Fabian, A.; Waning, J.; Mally, S.; Noël, J.; Schwab, A.; Stock, C. pH dependence of melanoma cell migration: Protons extruded by NHE1 dominate protons of the bulk solution. J. Physiol. 2007, 585, 351-360. [CrossRef]

21. Ludwig, F.T.; Schwab, A.; Stock, C. The $\mathrm{Na}^{+} / \mathrm{H}^{+}$-exchanger (NHE1) generates $\mathrm{pH}$ nanodomains at focal adhesions. J. Cell. Physiol. 2013, 228, 1351-1358. [CrossRef]

22. Kondapalli, K.C.; Llongueras, J.P.; Capilla-González, V.; Prasad, H.; Hack, A.; Smith, C.; Guerrero-Cázares, H.; Quiñones-Hinojosa, A.; Rao, R. A leak pathway for luminal protons in endosomes drives oncogenic signalling in glioblastoma. Nat. Commun. 2015, 6, 1-15. [CrossRef] [PubMed]

23. Chen, J.; Yang, H.; Wen, J.; Luo, K.; Liu, Q.; Huang, Y.; Zheng, Y.; Tan, Z.; Huang, Q.; Fu, J. NHE9 induces chemoradiotherapy resistance in esophageal squamous cell carcinoma by upregulating the Src/Akt/ $\beta$-catenin pathway and Bcl-2 expression. Oncotarget 2015, 6, 12405-12420. [CrossRef]

24. Lucien, F.; Pelletier, P.P.; Lavoie, R.R.; Lacroix, J.M.; Roy, S.; Parent, J.L.; Arsenault, D.; Harper, K.; Dubois, C.M. Hypoxia-induced mobilization of NHE6 to the plasma membrane triggers endosome hyperacidification and chemoresistance. Nat. Commun. 2017, 8, 1-15. [CrossRef] [PubMed]

25. Lambert, D.W.; Wood, I.S.; Ellis, A.; Shirazi-Beechey, S.P. Molecular changes in the expression of human colonic nutrient transporters during the transition from normality to malignancy. Br. J. Cancer 2002, 86, 1262-1269. [CrossRef] [PubMed]

26. Pinheiro, C.; Longatto-Filho, A.; Scapulatempo, C.; Ferreira, L.; Martins, S.; Pellerin, L.; Rodrigues, M.; Alves, V.A.F.; Schmitt, F.; Baltazar, F. Increased expression of monocarboxylate transporters 1, 2, and 4 in colorectal carcinomas. Virchows Arch. 2008, 452, 139-146. [CrossRef] [PubMed]

27. Pinheiro, C.; Reis, R.M.; Ricardo, S.; Longatto-Filho, A.; Schmitt, F.; Baltazar, F. Expression of monocarboxylate transporters 1, 2, and 4 in human tumours and their association with CD147 and CD44. J. Biomed. Biotechnol. 2010, 2010, 427694. [CrossRef] [PubMed]

28. Pinheiro, C.; Longatto-Filho, A.; Azevedo-Silva, J.; Casal, M.; Schmitt, F.C.; Baltazar, F. Role of monocarboxylate transporters in human cancers: State of the art. J. Bioenerg. Biomembr. 2012, 44, 127-139. [CrossRef]

29. Bröer, S.; Schneider, H.P.; Bröer, A.; Rahman, B.; Hamprecht, B.; Deitmer, J.W. Characterization of the monocarboxylate transporter 1 expressed in Xenopus laevis oocytes by changes in cytosolic $\mathrm{pH}$. Biochem. J. 1998, 333, 167-174. [CrossRef]

30. Halestrap, A.P. The monocarboxylate transporter family-Structure and functional characterization. IUBMB Life 2012, 64, 1-9. [CrossRef]

31. Forero-Quintero, L.S.; Deitmer, J.W.; Becker, H.M. Reduction of epileptiform activity in ketogenic mice: The role of monocarboxylate transporters. Sci. Rep. 2017, 7, 4900. [CrossRef]

32. Silva, L.S.; Poschet, G.; Nonnenmacher, Y.; Becker, H.M.; Sapcariu, S.; Gaupel, A.; Schlotter, M.; Wu, Y.; Kneisel, N.; Seiffert, M.; et al. Branched-chain ketoacids secreted by glioblastoma cells via MCT1 modulate macrophage phenotype. EMBO Rep. 2017, e201744154. 
33. Parks, S.K.; Chiche, J.; Pouysségur, J. Disrupting proton dynamics and energy metabolism for cancer therapy. Nat. Rev. Cancer 2013, 13, 611-623. [CrossRef] [PubMed]

34. Deitmer, J.W.; Schlue, W.R. An inwardly directed electrogenic sodium-bicarbonate co-transport in leech glial cells. J. Physiol. 1989, 411, 179-194. [CrossRef] [PubMed]

35. Choi, I.; Aalkjaer, C.; Boulpaep, E.L.; Boron, W.F. An electroneutral sodium/bicarbonate cotransporter NBCn1 and associated sodium channel. Nature 2000, 405, 571-575. [CrossRef]

36. Gross, E.; Hawkins, K.; Pushkin, A.; Sassani, P.; Dukkipati, R.; Abuladze, N.; Hopfer, U.; Kurtz, I. Phosphorylation of Ser (982) in the sodium bicarbonate cotransporter kNBC1 shifts the $\mathrm{HCO}(3)(-): \mathrm{Na}(+)$ stoichiometry from 3:1 to 2:1 in murine proximal tubule cells. J. Physiol. 2001, 537, 659-665. [CrossRef]

37. Boedtkjer, E.; Moreira, J.M.A.; Mele, M.; Vahl, P.; Wielenga, V.T.; Christiansen, P.M.; Jensen, V.E.D.; Pedersen, S.F.; Aalkjaer, C. Contribution of $\mathrm{Na}^{+}, \mathrm{HCO}_{3}{ }^{-}$-cotransport to cellular $\mathrm{pH}$ control in human breast cancer: A role for the breast cancer susceptibility locus NBCn1 (SLC4A7). Int. J. Cancer 2013, 132, 1288-1299. [CrossRef]

38. Boedtkjer, E. $\mathrm{Na}^{+}, \mathrm{HCO}_{3}{ }^{-}$cotransporter $\mathrm{NBCn} 1$ accelerates breast carcinogenesis. Cancer Metastasis Rev. 2019, 38, 165-178. [CrossRef]

39. Svastova, E.; Witarski, W.; Csaderova, L.; Kosik, I.; Skvarkova, L.; Hulikova, A.; Zatovicova, M.; Barathova, M.; Kopacek, J.; Pastorek, J.; et al. Carbonic anhydrase IX interacts with bicarbonate transporters in lamellipodia and increases cell migration via its catalytic domain. J. Biol. Chem. 2012, 287, 3392-3402. [CrossRef]

40. Parks, S.K.; Chiche, J.; Pouyssegur, J. pH control mechanisms of tumor survival and growth. J. Cell. Physiol. 2011, 226, 299-308. [CrossRef]

41. Gorbatenko, A.; Olesen, C.W.; Boedtkjer, E.; Pedersen, S.F. Regulation and roles of bicarbonate transporters in cancer. Front. Physiol. 2014, 5, 130. [CrossRef]

42. Loncaster, J.; Harris, A.L.; Davidson, S.; Logue, J.; Hunter, R.; Wycoff, C.; Pastorek, J.; Ratcliffe, P.; Stratford, I.; West, C. CAIX expression, a potential new intrinsic marker of hypoxia: Correlations with tumour oxygen measurements and prognosis in locally advanced carcinoma of the cervix. Cancer Res. 2001, 61, 6394-6399. [PubMed]

43. Tan, E.Y.; Yan, M.; Campo, L.; Han, C.; Takano, E.; Turley, H.; Candiloro, I.; Pezzella, F.; Gatter, K.C.; Millar, E.K.A.; et al. The key hypoxia regulated gene CAIX is upregulated in basal-like breast tumours and is associated with resistance to chemotherapy. Br. J. Cancer 2009, 100, 405-411. [CrossRef] [PubMed]

44. van Kuijk, S.J.A.; Yaromina, A.; Houben, R.; Niemans, R.; Lambin, P.; Dubois, L.J. Prognostic Significance of Carbonic Anhydrase IX Expression in Cancer Patients: A Meta-Analysis. Front. Oncol. 2016, 6, 1-16. [CrossRef] [PubMed]

45. Závada, J.; Závadová, Z.; Pastorek, J.; Biesová, Z.; Jez, J.; Jezek, J.; Velek, J. Human tumour-associated cell adhesion protein MN/CA IX: Identification of M75 epitope and of the region mediating cell adhesion. Br. J. Cancer 2000, 82, 1808-1813. [CrossRef] [PubMed]

46. Csaderova, L.; Debreova, M.; Radvak, P.; Stano, M.; Vrestiakova, M.; Kopacek, J.; Pastorekova, S.; Svastova, E. The effect of carbonic anhydrase IX on focal contacts during cell spreading and migration. Front. Physiol. 2013, 4, 271. [CrossRef]

47. Lee, S.-H.; McIntyre, D.; Honess, D.; Hulikova, A.; Pacheco-Torres, J.; Cerdán, S.; Swietach, P.; Harris, A.L.; Griffiths, J.R. Carbonic anhydrase IX is a $\mathrm{pH}$-stat that sets an acidic tumour extracellular $\mathrm{pH}$ in vivo. Br. J. Cancer 2018, 1-9. [CrossRef]

48. Ilie, M.I.; Hofman, V.; Ortholan, C.; Ammadi, R.E.; Bonnetaud, C.; Havet, K.; Venissac, N.; Mouroux, J.; Mazure, N.M.; Pouysségur, J.; et al. Overexpression of carbonic anhydrase XII in tissues from resectable non-small cell lung cancers is a biomarker of good prognosis. Int. J. Cancer 2011, 128, 1614-1623. [CrossRef]

49. Chien, M.H.; Ying, T.H.; Hsieh, Y.H.; Lin, C.H.; Shih, C.H.; Wei, L.H.; Yang, S.F. Tumor-associated carbonic anhydrase XII is linked to the growth of primary oral squamous cell carcinoma and its poor prognosis. Oral Oncol. 2012, 48, 417-423. [CrossRef]

50. Kopecka, J.; Campia, I.; Jacobs, A.; Frei, A.P.; Ghigo, D.; Wollscheid, B.; Riganti, C. Carbonic anhydrase $\mathrm{XII}$ is a new therapeutic target to overcome chemoresistance in cancer cells. Oncotarget 2015, 6, 6776-6793. [CrossRef]

51. Salaroglio, I.C.; Mujumdar, P.; Annovazzi, L.; Kopecka, J.; Mellai, M.; Schiffer, D.; Poulsen, S.-A.; Riganti, C. Carbonic Anhydrase XII Inhibitors Overcome P-Glycoprotein-Mediated Resistance to Temozolomide in Glioblastoma. Mol. Cancer Ther. 2018, 17, 2598-2609. [CrossRef] 
52. Mboge, M.Y.; Mahon, B.P.; McKenna, R.; Frost, S.C. Carbonic Anhydrases: Role in pH Control and Cancer. Metabolites 2018, 8. [CrossRef] [PubMed]

53. Srere, P.A. The metabolon. Trends Biochem. Sci. 1985, 10, 109-110. [CrossRef]

54. Srere, P.A. Complexes Of Sequential Metabolic Enzymes. Annu. Rev. Biochem. 1987, 56, 89-124. [CrossRef] [PubMed]

55. Deitmer, J.W.; Becker, H.M. Transport metabolons with carbonic anhydrases. Front. Physiol. 2013, 4, 291. [CrossRef]

56. Vince, J.W.; Reithmeier, R.A.F. Carbonic anhydrase II binds to the carboxyl terminus of human band 3, the erythrocyte $\mathrm{C}^{-}{ }^{-} / \mathrm{HCO}_{3}{ }^{-}$exchanger. J. Biol. Chem. 1998, 273, 28430-28437. [CrossRef]

57. Vince, J.W.; Reithmeier, R.A.F. Identification of the carbonic anhydrase II binding site in the $\mathrm{Cl}(-) / \mathrm{HCO}(3)(-)$ anion exchanger AE1. Biochemistry 2000, 39, 5527-5533. [CrossRef]

58. Dahl, N.K.; Jiang, L.; Chernova, M.N.; Stuart-Tilley, A.K.; Shmukler, B.E.; Alper, S.L. Deficient $\mathrm{HCO}_{3}{ }^{-}$ transport in an AE1 mutant with normal $\mathrm{Cl}^{-}$transport can be rescued by carbonic anhydrase II presented on an adjacent AE1 protomer. J. Biol. Chem. 2003, 278, 44949-44958. [CrossRef]

59. Shen, W.W.; Wu, J.; Cai, L.; Liuz, B.Y.; Gao, Y.; Chen, G.Q.; Fu, G.H. Expression of anion exchanger 1 sequestrates p16 in the cytoplasm in gastric and colonic adenocarcinoma. Neoplasia 2007, 9, 812-819. [CrossRef]

60. Shiozaki, A.; Kudou, M.; Ichikawa, D.; Shimizu, H.; Arita, T.; Kosuga, T.; Konishi, H.; Komatsu, S.; Fujiwara, H.; Okamoto, K.; et al. Expression and role of anion exchanger 1 in esophageal squamous cell carcinoma. Oncotarget 2017, 8, 17921-17935. [CrossRef]

61. Sterling, D.; Reithmeier, R.A.F.; Casey, J.R. A transport metabolon: Functional interaction of carbonic anhydrase II and chloride/bicarbonate exchangers. J. Biol. Chem. 2001, 276, 47886-47894. [CrossRef]

62. Gross, E.; Pushkin, A.; Abuladze, N.; Fedotoff, O.; Kurtz, I. Regulation of the sodium bicarbonate cotransporter kNBC1 function: Role of Asp986, Asp988 and kNBC1-carbonic anhydrase II binding. J. Physiol. 2002, 544, 679-685. [CrossRef] [PubMed]

63. Pushkin, A.; Abuladze, N.; Gross, E.; Newman, D.; Tatishchev, S.; Lee, I.; Fedotoff, O.; Bondar, G.; Azimov, R.; Ngyuen, M.; et al. Molecular mechanism of kNBC1-carbonic anhydrase II interaction in proximal tubule cells. J. Physiol. 2004, 559, 55-65. [CrossRef] [PubMed]

64. Loiselle, F.B.; Morgan, P.E.; Alvarez, B.V.; Casey, J.R. Regulation of the human $\mathrm{NBC} 3 \mathrm{Na}^{+} / \mathrm{HCO}_{3}{ }^{-}$cotransporter by carbonic anhydrase II and PKA. Am. J. Physiol. Cell Physiol. 2004, 286, C1423-C1433. [CrossRef] [PubMed]

65. Becker, H.M.; Deitmer, J.W. Carbonic anhydrase II increases the activity of the human electrogenic $\mathrm{Na}^{+} / \mathrm{HCO}_{3}{ }^{-}$ cotransporter. J. Biol. Chem. 2007, 282, 13508-13521. [CrossRef]

66. Schüler, C.; Becker, H.M.; McKenna, R.; Deitmer, J.W. Transport activity of the sodium bicarbonate cotransporter NBCe1 is enhanced by different isoforms of carbonic anhydrase. PLoS ONE 2011, 6, e27167. [CrossRef]

67. Li, X.; Alvarez, B.V.; Casey, J.R.; Reithmeier, R.A.F.; Fliegel, L. Carbonic anhydrase II binds to and enhances activity of the $\mathrm{Na}^{+} / \mathrm{H}^{+}$exchanger. J. Biol. Chem. 2002, 277, 36085-36091. [CrossRef]

68. Krishnan, D.; Liu, L.; Wiebe, S.A.; Casey, J.R.; Cordat, E.; Alexander, R.T. Carbonic anhydrase II binds to and increases the activity of the epithelial sodium-proton exchanger, NHE3. Am. J. Physiol.-Ren. Physiol. 2015, 309, F383-F392. [CrossRef]

69. Jaquenod De Giusti, C.; Blanco, P.G.; Lamas, P.A.; Carrizo Velasquez, F.; Lofeudo, J.M.; Portiansky, E.L.; Alvarez, B. V Carbonic anhydrase II/sodium-proton exchanger 1 metabolon complex in cardiomyopathy of $\mathrm{ob}^{-/-}$type 2 diabetic mice. J. Mol. Cell. Cardiol. 2019, 136, 53-63. [CrossRef]

70. Sterling, D.; Alvarez, B.V.; Casey, J.R. The extracellular component of a transport metabolon: Extracellular loop 4 of the human $\mathrm{AE} 1 \mathrm{Cl}^{-} / \mathrm{HCO}_{3}{ }^{-}$exchanger binds carbonic anhydrase IV. J. Biol. Chem. 2002, 277, 25239-25246. [CrossRef]

71. Alvarez, B.V.; Loiselle, F.B.; Supuran, C.T.; Schwartz, G.J.; Casey, J.R. Direct Extracellular Interaction between Carbonic Anhydrase IV and the Human NBC1 Sodium/Bicarbonate Co-Transporter. Biochemistry 2003, 42, 12321-12329. [CrossRef]

72. Morgan, P.E.; Pastorekova, S.; Stuart-Tilley, A.K.; Alper, S.L.; Casey, J.R. Interactions of transmembrane carbonic anhydrase, CAIX, with bicarbonate transporters. AJP Cell Physiol. 2007, 293, C738-C748. [CrossRef] [PubMed] 
73. Orlowski, A.; De Giusti, V.C.; Morgan, P.E.; Aiello, E.A.; Alvarez, B.V. Binding of carbonic anhydrase IX to extracellular loop 4 of the $\mathrm{NBCe} 1 \mathrm{Na}^{+} / \mathrm{HCO}_{3}{ }^{-}$cotransporter enhances $\mathrm{NBCe} 1$-mediated $\mathrm{HCO}_{3}{ }^{-}$influx in the rat heart. Am. J. Physiol. Cell Physiol. 2012, 303, C69-C80. [CrossRef]

74. Kifor, G.; Toon, M.R.; Janoshazi, A.; Solomon, A.K. Interaction between red cell membrane band 3 and cytosolic carbonic anhydrase. J. Membr. Biol. 1993, 134, 169-179. [CrossRef] [PubMed]

75. Vince, J.W.; Carlsson, U.; Reithmeier, R.A.F. Localization of the $\mathrm{Cl}^{-} / \mathrm{HCO}_{3}{ }^{-}$anion exchanger binding site to the amino-terminal region of carbonic anhydrase II. Biochemistry 2000, 39, 13344-13349. [CrossRef] [PubMed]

76. Tang, X.B.; Fujinaga, J.; Kopito, R.; Casey, J.R. Topology of the region surrounding Glu681 of human AE1 protein, the erythrocyte anion exchanger. J. Biol. Chem. 1998, 273, 22545-22553. [CrossRef] [PubMed]

77. Casey, J.R.; Sly, W.S.; Shah, G.N.; Alvarez, B.V. Bicarbonate homeostasis in excitable tissues: Role of AE3 $\mathrm{Cl}^{-} / \mathrm{HCO}_{3}{ }^{-}$exchanger and carbonic anhydrase XIV interaction. Am. J. Physiol. Cell Physiol. 2009, 297, 1091-1102. [CrossRef] [PubMed]

78. Alvarez, B.V.; Vilas, G.L.; Casey, J.R. Metabolon disruption: A mechanism that regulates bicarbonate transport. EMBO J. 2005, 24, 2499-2511. [CrossRef]

79. Ro, H.; Carson, J.H. pH microdomains in oligodendrocytes. J. Biol. Chem. 2004, 279, 37115-37123. [CrossRef]

80. Debreova, M.; Csaderova, L.; Burikova, M.; Lukacikova, L.; Kajanova, I.; Sedlakova, O.; Kery, M.; Kopacek, J.; Zatovicova, M.; Bizik, J.; et al. CAIX regulates invadopodia formation through both a pH-dependent mechanism and interplay with actin regulatory proteins. Int. J. Mol. Sci. 2019, 20, 2745. [CrossRef]

81. Liskova, V.; Hudecova, S.; Lencesova, L.; Iuliano, F.; Sirova, M.; Ondrias, K.; Pastorekova, S.; Krizanova, O. Type 1 Sodium Calcium Exchanger Forms a Complex with Carbonic Anhydrase IX and Via Reverse Mode Activity Contributes to $\mathrm{pH}$ Control in Hypoxic Tumors. Cancers (Basel). 2019, 11, 1139. [CrossRef]

82. Li, X.; Liu, Y.; Alvarez, B.V.; Casey, J.R.; Fliegel, L. A novel carbonic anhydrase II binding site regulates NHE1 activity. Biochemistry 2006, 45, 2414-2424. [CrossRef] [PubMed]

83. Wu, Q.; Pierce, W.M.; Delamere, N.A. Cytoplasmic $\mathrm{pH}$ responses to carbonic anhydrase inhibitors in cultured rabbit nonpigmented ciliary epithelium. J. Membr. Biol. 1998, 162, 31-38. [CrossRef] [PubMed]

84. Weise, A.; Becker, H.M.; Deitmer, J.W. Enzymatic suppression of the membrane conductance associated with the glutamine transporter SNAT3 expressed in Xenopus oocytes by carbonic anhydrase II. J. Gen. Physiol. 2007, 130, 203-215. [CrossRef] [PubMed]

85. Weise, A.; Schneider, H.-P.; McKenna, R.; Deitmer, J.W. Substrate-dependent interference of carbonic anhydrases with the glutamine transporter SNAT3-induced conductance. Cell. Physiol. Biochem. 2011, 27, 79-90. [CrossRef]

86. Becker, H.M.; Hirnet, D.; Fecher-Trost, C.; Sültemeyer, D.; Deitmer, J.W. Transport activity of MCT1 expressed in Xenopus oocytes is increased by interaction with carbonic anhydrase. J. Biol. Chem. 2005, 280, 39882-39889. [CrossRef]

87. Becker, H.M.; Deitmer, J.W. Nonenzymatic proton handling by carbonic anhydrase II during $\mathrm{H}^{+}$-lactate cotransport via monocarboxylate transporter 1. J. Biol. Chem. 2008, 283, 21655-21667. [CrossRef]

88. Becker, H.M.; Klier, M.; Schüler, C.; McKenna, R.; Deitmer, J.W. Intramolecular proton shuttle supports not only catalytic but also noncatalytic function of carbonic anhydrase II. Proc. Natl. Acad. Sci. USA 2011, 108, 3071-3076. [CrossRef]

89. Stridh, M.H.; Alt, M.D.; Wittmann, S.; Heidtmann, H.; Aggarwal, M.; Riederer, B.; Seidler, U.; Wennemuth, G.; McKenna, R.; Deitmer, J.W.; et al. Lactate flux in astrocytes is enhanced by a non-catalytic action of carbonic anhydrase II. J. Physiol. 2012, 590, 2333-2351. [CrossRef]

90. Klier, M.; Andes, F.T.; Deitmer, J.W.; Becker, H.M. Intracellular and extracellular carbonic anhydrases cooperate non-enzymatically to enhance activity of monocarboxylate transporters. J. Biol. Chem. 2014, 289, 2765-2775. [CrossRef]

91. Jamali, S.; Klier, M.; Ames, S.; Barros, L.F.; McKenna, R.; Deitmer, J.W.; Becker, H.M. Hypoxia-induced carbonic anhydrase IX facilitates lactate flux in human breast cancer cells by non-catalytic function. Sci. Rep. 2015, 5, 13605. [CrossRef]

92. Noor, S.I.; Jamali, S.; Ames, S.; Langer, S.; Deitmer, J.W.; Becker, H.M. A surface proton antenna in carbonic anhydrase II supports lactate transport in cancer cells. Elife 2018, 7, 1-31. [CrossRef] [PubMed]

93. Hiremath, S.A.; Surulescu, C.; Jamali, S.; Ames, S.; Deitmer, J.W.; Becker, H.M. Modeling of pH regulation in tumor cells: Direct interaction between proton-coupled lactate transporters and cancer-associated carbonic anhydrase. Math. Biosci. Eng. 2018, 16, 320-337. [CrossRef] [PubMed] 
94. Forero-Quintero, L.S.; Ames, S.; Schneider, H.-P.; Thyssen, A.; Boone, C.D.; Andring, J.T.; McKenna, R.; Casey, J.R.; Deitmer, J.W.; Becker, H.M. Membrane-anchored carbonic anhydrase IV interacts with monocarboxylate transporters via their chaperones CD147 and GP70. J. Biol. Chem. 2018, 294, 593-607. [CrossRef] [PubMed]

95. Ames, S.; Pastorekova, S.; Becker, H.M. The proteoglycan-like domain of carbonic anhydrase IX mediates non-catalytic facilitation of lactate transport in cancer cells. Oncotarget 2018, 9, 27940-27957. [CrossRef] [PubMed]

96. Ames, S.; Andring, J.T.; McKenna, R.; Becker, H.M. CAIX forms a transport metabolon with monocarboxylate transporters in human breast cancer cells. Oncogene 2019, 39, 1710-1723. [CrossRef]

97. Klier, M.; Schüler, C.; Halestrap, A.P.; Sly, W.S.; Deitmer, J.W.; Becker, H.M. Transport activity of the high-affinity monocarboxylate transporter MCT2 is enhanced by extracellular carbonic anhydrase IV but not by intracellular carbonic anhydrase II. J. Biol. Chem. 2011, 286, 27781-27791. [CrossRef]

98. Noor, S.I.; Dietz, S.; Heidtmann, H.; Boone, C.D.; McKenna, R.; Deitmer, J.W.; Becker, H.M. Analysis of the binding moiety mediating the interaction between monocarboxylate transporters and carbonic anhydrase II. J. Biol. Chem. 2015, 290, 4476-4486. [CrossRef]

99. Becker, H.M.; Klier, M.; Deitmer, J.W. Nonenzymatic augmentation of lactate transport via monocarboxylate transporter isoform 4 by carbonic anhydrase II. J. Membr. Biol. 2010, 234, 125-135. [CrossRef]

100. Noor, S.I.; Pouyssegur, J.; Deitmer, J.W.; Becker, H.M. Integration of a 'proton antenna' facilitates transport activity of the monocarboxylate transporter MCT4. FEBS J. 2017, 284, 149-162. [CrossRef]

101. Mboge, M.Y.; Chen, Z.; Khokhar, D.; Wolff, A.; Ai, L.; Heldermon, C.D.; Bozdag, M.; Carta, F.; Supuran, C.T.; Brown, K.D.; et al. A non-catalytic function of carbonic anhydrase IX contributes to the glycolytic phenotype and $\mathrm{pH}$ regulation in human breast cancer cells. Biochem. J. 2019, 476, 1497-1513. [CrossRef]

102. Piermarini, P.M.; Kim, E.Y.; Boron, W.F. Evidence against a direct interaction between intracellular carbonic anhydrase II and pure C-terminal domains of SLC4 bicarbonate transporters. J. Biol. Chem. 2007, 282, 1409-1421. [CrossRef] [PubMed]

103. Yamada, H.; Horita, S.; Suzuki, M.; Fujita, T.; Seki, G. Functional role of a putative carbonic anhydrase II-binding domain in the electrogenic $\mathrm{Na}^{+}-\mathrm{HCO}_{3}{ }^{-}$cotransporter NBCe1 expressed in Xenopus oocytes. Channels (Austin). 2011, 5, 106-109. [CrossRef] [PubMed]

104. Villafuerte, F.C.; Swietach, P.; Youm, J.-B.; Ford, K.; Cardenas, R.; Supuran, C.T.; Cobden, P.M.; Rohling, M.; Vaughan-Jones, R.D. Facilitation by intracellular carbonic anhydrase of $\mathrm{Na}^{+}-\mathrm{HCO}_{3}{ }^{-}$co-transport but not $\mathrm{Na}^{+} / \mathrm{H}^{+}$ exchange activity in the mammalian ventricular myocyte. J. Physiol. 2014, 592, 991-1007. [CrossRef] [PubMed]

105. Al-Samir, S.; Papadopoulos, S.; Scheibe, R.J.; Meißner, J.D.; Cartron, J.-P.; Sly, W.S.; Alper, S.L.; Gros, G.; Endeward, V. Activity and distribution of intracellular carbonic anhydrase II and their effects on the transport activity of anion exchanger AE1/SLC4A1. J. Physiol. 2013, 591, 4963-4982. [CrossRef] [PubMed]

106. Johnson, D.E.; Casey, J.R. Bicarbonate Transport Metabolons. In Drug Design of Zinc-Enzyme Inhibitors; John Wiley \& Sons, Inc.: Hoboken, NJ, USA, 2009; pp. 415-437.

107. Moraes, T.F.; Reithmeier, R.A.F. Membrane transport metabolons. Biochim. Biophys. Acta-Biomembr. 2012, 1818, 2687-2706. [CrossRef]

108. Becker, H.M.; Klier, M.; Deitmer, J.W. Carbonic anhydrases and their interplay with acid/base-coupled membrane transporters. In Sub-cellular biochemistry; Frost, S.C., McKenna, R., Eds.; Subcellular Biochemistry; Springer: Dordrecht, The Netherlands, 2014; ISBN 978-94-007-7358-5.

109. Nachliel, E.; Gutman, M.; Kiryati, S.; Dencher, N.A.; Gutman, M. Protonation dynamics of the extracellular and cytoplasmic surface of bacteriorhodopsin in the purple membrane. Proc. Natl. Acad. Sci. USA 1996, 93, 10747-10752. [CrossRef]

110. Marantz, Y.; Nachliel, E.; Aagaard, A.; Brzezinski, P.; Gutman, M. The proton collecting function of the inner surface of cytochrome c oxidase from Rhodobacter sphaeroides. Proc. Natl. Acad. Sci. USA 1998, 95, 8590-8595. [CrossRef]

111. Ädelroth, P.; Brzezinski, P. Surface-mediated proton-transfer reactions in membrane-bound proteins. Biochim. Biophys. Acta-Bioenerg. 2004, 1655, 102-115. [CrossRef]

112. Fisher, S.Z.; Maupin, C.M.; Budayova-Spano, M.; Govindasamy, L.; Tu, C.; Agbandje-McKenna, M.; Silverman, D.N.; Voth, G.A.; McKenna, R. Atomic crystal and molecular dynamics simulation structures of human carbonic anhydrase II: Insights into the proton transfer mechanism. Biochemistry 2007, 46, 2930-2937. [CrossRef] 
113. Shinobu, A.; Agmon, N. Mapping proton wires in proteins: Carbonic anhydrase and GFP chromophore biosynthesis. J. Phys. Chem. A 2009, 113, 7253-7266. [CrossRef]

114. Innocenti, A.; Pastorekova, S.; Pastorek, J.; Scozzafava, A.; De Simone, G.; Supuran, C.T. The proteoglycan region of the tumor-associated carbonic anhydrase isoform IX acts as anintrinsic buffer optimizing $\mathrm{CO}_{2}$ hydration at acidic $\mathrm{pH}$ values characteristic of solid tumors. Bioorg. Med. Chem. Lett. 2009, 19, 5825-5828. [CrossRef] [PubMed]

115. Brown, B.F.; Quon, A.; Dyck, J.R.B.; Casey, J.R. Carbonic anhydrase II promotes cardiomyocyte hypertrophy. Can. J. Physiol. Pharmacol. 2012, 90, 1599-1610. [CrossRef] [PubMed]

116. Svichar, N.; Chesler, M. Surface carbonic anhydrase activity on astrocytes and neurons facilitates lactate transport. Glia 2003, 41, 415-419. [CrossRef] [PubMed]

117. Svichar, N.; Waheed, A.; Sly, W.S.; Hennings, J.C.; Hubner, C.A.; Chesler, M. Carbonic Anhydrases CA4 and CA14 Both Enhance AE3-Mediated $\mathrm{Cl}^{-}-\mathrm{HCO}_{3}{ }^{-}$Exchange in Hippocampal Neurons. J. Neurosci. 2009, 29, 3252-3258. [CrossRef] [PubMed]

118. Gatenby, R.A.; Gillies, R.J. Why do cancers have high aerobic glycolysis? Nat. Rev. Cancer 2004, 4, 891-899. [CrossRef] [PubMed]

119. Gillies, R.J.; Robey, I.; Gatenby, R.A. Causes and consequences of increased glucose metabolism of cancers. J. Nucl. Med. 2008, 49, 24-43. [CrossRef]

120. Doherty, J.R.; Yang, C.; Scott, K.E.N.; Cameron, M.D.; Fallahi, M.; Li, W.; Hall, M.A.; Amelio, A.L.; Mishra, J.K.; $\mathrm{Li}, \mathrm{F}$; et al. Blocking lactate export by inhibiting the myc target MCT1 disables glycolysis and glutathione synthesis. Cancer Res. 2014, 74, 908-920. [CrossRef]

121. Parks, S.K.; Cormerais, Y.; Marchiq, I.; Pouyssegur, J. Hypoxia optimises tumour growth by controlling nutrient import and acidic metabolite export. Mol. Aspects Med. 2016, 47-48, 3-14. [CrossRef]

122. Ullah, M.S.; Davies, A.J.; Halestrap, A.P. The plasma membrane lactate transporter MCT4, but not MCT1, is up-regulated by hypoxia through a HIF-1 $\alpha$-dependent mechanism. J. Biol. Chem. 2006, 281, 9030-9037. [CrossRef]

123. Meijer, T.W.H.; Schuurbiers, O.C.J.; Kaanders, J.H.A.M.; Looijen-Salamon, M.G.; de Geus-Oei, L.F.; Verhagen, A.F.T.M.; Lok, J.; van der Heijden, H.F.M.; Rademakers, S.E.; Span, P.N.; et al. Differences in metabolism between adeno- and squamous cell non-small cell lung carcinomas: Spatial distribution and prognostic value of GLUT1 and MCT4. Lung Cancer 2012, 76, 316-323. [CrossRef]

124. Choi, J.H.; Lim, I.; Noh, W.C.; Kim, H.-A.; Seong, M.-K.; Jang, S.; Seol, H.; Moon, H.; Byun, B.H.; Kim, B.I.; et al. Prediction of tumor differentiation using sequential PET/CT and MRI in patients with breast cancer. Ann. Nucl. Med. 2018, 32, 389-397. [CrossRef] [PubMed]

125. Gatenby, R.A.; Smallbone, K.; Maini, P.K.; Rose, F.; Averill, J.; Nagle, R.B.; Worrall, L.; Gillies, R.J. Cellular adaptations to hypoxia and acidosis during somatic evolution of breast cancer. Br. J. Cancer 2007, 97, 646-653. [CrossRef]

126. Waterman, E.A.; Cross, N.A.; Lippitt, J.M.; Cross, S.S.; Rehman, I.; Holen, I.; Hamdy, F.C.; Eaton, C.L. The antibody MAB8051 directed against osteoprotegerin detects carbonic anhydrase II: Implications for association studies with human cancers. Int. J. Cancer 2007, 121, 1958-1966. [CrossRef] [PubMed]

127. Parkkila, S.; Lasota, J.; Fletcher, J.A.; Ou, W.B.; Kivelä, A.J.; Nuorva, K.; Parkkila, A.K.; Ollikainen, J.; Sly, W.S.; Waheed, A.; et al. Carbonic anhydrase II. A novel biomarker for gastrointestinal stromal tumors. Mod. Pathol. 2010, 23, 743-750. [CrossRef] [PubMed]

128. Zhou, R.; Huang, W.; Yao, Y.; Wang, Y.; Li, Z.; Shao, B.; Zhong, J.; Tang, M.; Liang, S.; Zhao, X.; et al. CA II, a potential biomarker by proteomic analysis, exerts significant inhibitory effect on the growth of colorectal cancer cells. Int. J. Oncol. 2013, 43, 611-621. [CrossRef] [PubMed]

129. Zhou, Y.; Mokhtari, R.B.; Pan, J.; Cutz, E.; Yeger, H. Carbonic anhydrase II mediates malignant behavior of pulmonary neuroendocrine tumors. Am. J. Respir. Cell Mol. Biol. 2015, 52, 183-192. [CrossRef] [PubMed]

130. Becker, H.M. Carbonic anhydrase IX and acid transport in cancer. Br. J. Cancer 2019, 75, 199-219. [CrossRef]

131. Klein, M.; Seeger, P.; Schuricht, B.; Alper, S.L.; Schwab, A. Polarization of $\mathrm{Na}(+) / \mathrm{H}(+)$ and $\mathrm{Cl}(-) / \mathrm{HCO}(3)(-)$ exchangers in migrating renal epithelial cells. J. Gen. Physiol. 2000, 115, 599-608. [CrossRef]

132. Stock, C.; Gassner, B.; Hauck, C.R.; Arnold, H.; Mally, S.; Eble, J.A.; Dieterich, P.; Schwab, A. Migration of human melanoma cells depends on extracellular $\mathrm{pH}$ and $\mathrm{Na}^{+} / \mathrm{H}^{+}$exchange. J. Physiol. 2005, 567, $225-238$. [CrossRef] 
133. Stock, C.; Cardone, R.A.; Busco, G.; Krähling, H.; Schwab, A.; Reshkin, S.J. Protons extruded by NHE1: Digestive or glue? Eur. J. Cell Biol. 2008, 87, 591-599. [CrossRef]

134. Busco, G.; Cardone, R.A.; Greco, M.R.; Bellizzi, A.; Colella, M.; Antelmi, E.; Mancini, M.T.; Dell'Aquila, M.E.; Casavola, V.; Paradiso, A.; et al. NHE1 promotes invadopodial ECM proteolysis through acidification of the peri-invadopodial space. FASEB J. 2010, 24, 3903-3915. [CrossRef] [PubMed]

135. Denker, S.P.; Huang, D.C.; Orlowski, J.; Furthmayr, H.; Barber, D.L. Direct binding of the Na-H exchanger NHE1 to ERM proteins regulates the cortical cytoskeleton and cell shape independently of $\mathrm{H}(+)$ translocation. Mol. Cell 2000, 6, 1425-1436. [CrossRef]

136. Hoffmann, E.K.; Lambert, I.H.; Pedersen, S.F. Physiology of cell volume regulation in vertebrates. Physiol. Rev. 2009, 89, 193-277. [CrossRef] [PubMed]

137. Papadopoulos, M.C.; Saadoun, S.; Verkman, A.S. Aquaporins and cell migration. Pflugers Arch. Eur. J. Physiol. 2008, 456, 693-700. [CrossRef] [PubMed]

138. Boedtkjer, E.; Bentzon, J.F.; Dam, V.S.; Aalkjaer, C. $\mathrm{Na}^{+}, \mathrm{HCO}_{3}{ }^{-}$-cotransporter $\mathrm{NBCn} 1$ increases pH $\mathrm{H}_{\mathrm{i}}$ gradients, filopodia, and migration of smooth muscle cells and promotes arterial remodelling. Cardiovasc. Res. 2016, 111, 227-239. [CrossRef] [PubMed]

139. Gallagher, S.M.; Castorino, J.J.; Philp, N.J. Interaction of monocarboxylate transporter 4 with beta1-integrin and its role in cell migration. Am. J. Physiol. Cell Physiol. 2009, 296, C414-C421. [CrossRef]

140. Stock, C.; Pedersen, S.F. Roles of $\mathrm{pH}$ and the $\mathrm{Na}^{+} / \mathrm{H}^{+}$exchanger NHE1 in cancer: From cell biology and animal models to an emerging translational perspective? Semin. Cancer Biol. 2017, 43, 5-16. [CrossRef]

141. Boedtkjer, E.; Pedersen, S.F. The Acidic Tumor Microenvironment as a Driver of Cancer. Annu. Rev. Physiol. 2020, 82, 103-126. [CrossRef]

142. Svastova, E.; Pastorekova, S. Carbonic anhydrase IX. Cell Adh. Migr. 2013, 7, 226-231. [CrossRef]

143. Scozzafava, A.; Supuran, C.T. Glaucoma and the applications of carbonic anhydrase inhibitors. Subcell. Biochem. 2014, 75, 349-359.

144. Gupta, D.; Chen, P.P. Glaucoma. Am. Fam. Physician 2016, 93, 668-674. [PubMed]

145. Aggarwal, M.; Kondeti, B.; McKenna, R. Anticonvulsant/antiepileptic carbonic anhydrase inhibitors: A patent review. Expert Opin. Ther. Pat. 2013, 23, 717-724. [CrossRef] [PubMed]

146. Ruusuvuori, E.; Kaila, K. Carbonic anhydrases and brain $\mathrm{pH}$ in the control of neuronal excitability. Subcell. Biochem. 2014, 75, 271-290. [PubMed]

147. Swenson, E.R. Carbonic anhydrase inhibitors and high altitude illnesses. Subcell. Biochem. 2014, 75, 361-386.

148. Davis, C.; Hackett, P. Advances in the Prevention and Treatment of High Altitude Illness. Emerg. Med. Clin. North. Am. 2017, 35, 241-260. [CrossRef]

149. Singh, S.; Lomelino, C.L.; Mboge, M.Y.; Frost, S.C.; McKenna, R. Cancer drug development of carbonic anhydrase inhibitors beyond the active site. Molecules 2018, 23. [CrossRef]

150. Avkiran, M.; Marber, M.S. $\mathrm{Na}(+) / \mathrm{H}(+)$ exchange inhibitors for cardioprotective therapy: Progress, problems and prospects. J. Am. Coll. Cardiol. 2002, 39, 747-753. [CrossRef]

151. Avkiran, M.; Cook, A.R.; Cuello, F. Targeting $\mathrm{Na}^{+} / \mathrm{H}^{+}$exchanger regulation for cardiac protection: A RSKy approach? Curr. Opin. Pharmacol. 2008, 8, 133-140. [CrossRef]

152. Mentzer, R.M.; Bartels, C.; Bolli, R.; Boyce, S.; Buckberg, G.D.; Chaitman, B.; Haverich, A.; Knight, J.; Menasché, P.; Myers, M.L.; et al. Sodium-Hydrogen Exchange Inhibition by Cariporide to Reduce the Risk of Ischemic Cardiac Events in Patients Undergoing Coronary Artery Bypass Grafting: Results of the EXPEDITION Study. Ann. Thorac. Surg. 2008, 85, 1261-1270. [CrossRef]

153. Mboge, M.Y.; Brown, K.D.; Bozdag, M.; Chen, Z.; Carta, F.; Mathias, J.V.; Frost, S.C.; McKenna, R.; Supuran, C.T.; Wolff, A.; et al. Selective inhibition of carbonic anhydrase IX over carbonic anhydrase XII in breast cancer cells using benzene sulfonamides: Disconnect between activity and growth inhibition. PLoS ONE 2018, 13, e0207417. [CrossRef]

(C) 2020 by the authors. Licensee MDPI, Basel, Switzerland. This article is an open access article distributed under the terms and conditions of the Creative Commons Attribution (CC BY) license (http://creativecommons.org/licenses/by/4.0/). 